\title{
Pluri-annual Water Budget on the Seine Basin: Past, Current and Future Trends
}

\author{
Nicolas Flipo, Nicolas Gallois, Baptiste Labarthe, Fulvia Baratelli, \\ Pascal Viennot, Jonathan Schuite, Agnès Rivière, Rémy Bonnet, \\ and Julien Boé
}

\section{Contents}

1 Introduction

2 Historical Records of the Seine River Discharge in Paris ......................... 61

3 Development of the Seine Basin Model ..................................... 65

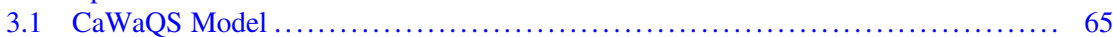

3.2 Implementation of the Seine Basin Model ............................... 66

4 Current State of the Seine Hydrosystem .................................. 66

4.1 General Two-Step Calibration Strategy of Hydrosystem Models ................ 67

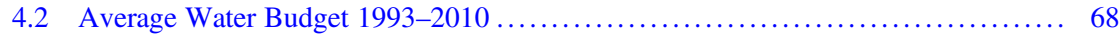

5 A Two-Century-Long Trajectory of the Seine Basin $\ldots \ldots \ldots \ldots \ldots \ldots \ldots \ldots \ldots \ldots \ldots \ldots$

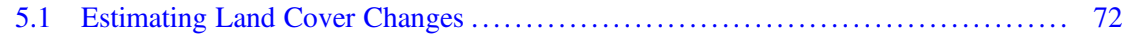

5.2 Estimating Anthropogenic Water Uptake $\ldots \ldots \ldots \ldots \ldots \ldots \ldots \ldots \ldots \ldots \ldots \ldots \ldots . \ldots \ldots$

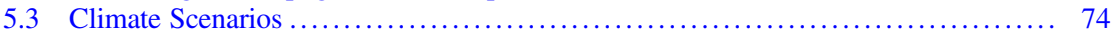

5.4 Water Resources Trajectory from the 1900 s to the $2100 \mathrm{~s} \ldots \ldots \ldots \ldots \ldots \ldots \ldots \ldots \ldots$

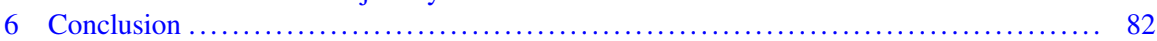

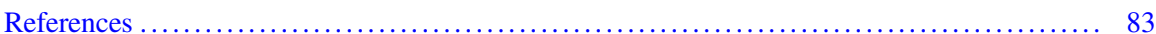

\begin{abstract}
The trajectory of the Seine basin water resources is rebuilt from the early 1900 s to the 2000 s before being projected to the end of the twenty-first century. In the first part, the long-term hydrological data of the Paris gauging stations are analysed beginning in 1885, highlighting the effect of anthropogenic water management on the Seine River discharge. Then a detailed water budget of the Seine basin is proposed. It quantifies for the first time the water exchanges between aquifer units and the effect of water withdrawals on river-aquifer exchanges. Using this model,
\end{abstract}

The copyright year of the original version of this chapter was corrected from 2019 to 2020 . A correction to this chapter can be found at https://doi.org/10.1007/698_2020_667

N. Flipo ( $ه)$, N. Gallois, B. Labarthe, F. Baratelli, P. Viennot, J. Schuite, and A. Rivière Geosciences Department, MINES ParisTech, PSL University, Fontainebleau, France e-mail: Nicolas.Flipo@mines-paristech.fr

R. Bonnet and J. Boé

CECI, Université de Toulouse, CNRS, CERFACS, Toulouse, France 
the trajectory of the system is evaluated based on a downscaled climate reanalysis of the twentieth century and a reconstruction of the land use in the early 1900s, as well as the choice of a climate projection which favours the model that best reproduces the low frequency of precipitation. The trajectory is synthesised as average regimes, revealing a relative stability of the hydrosystem up to the present, and drastic changes in the discharge regime in the future, especially concerning the decreased amount of low flow and its increased duration. These expected changes will require the definition of an adaptation strategy even though they are rather limited in the Seine basin when compared to other French regions.

Keywords CaWaQS, Climate change, Groundwater, Hydrological distributed modelling, Land use, Past and future scenarios, Seine basin, Surface water, Water budget

\section{Introduction}

As mentioned by Flipo et al. [1] and Billen et al. [2], the Seine hydrosystem is unique due to the tremendous pressure exerted by the largest metropolis in Europe, Greater Paris, on water resources and the fact that it contains the largest groundwater reservoir in Europe, the Paris basin [3]. Today, the total water withdrawal reaches the enormous amount of $3 \mathrm{Gm}^{3} \mathrm{a}^{-1}$. Coupled with climate change, this pressure may hinder the sustainability of this unique hydrosystem.

Since the international effort to quantify the effect of climate change on global water circulation crystallised around the successive climate model intercomparison projects $[4,5]$, the expected effects of climate change on French water resources have been estimated $[6,7]$. To evaluate water resources at the scale of a regional hydrosystem, it is now acknowledged that regional-scale models calibrated and validated against observed discharge should be used [8]. Following this effort, a first regional assessment at the Seine basin scale [9] led to the same conclusion as the nation-wide assessment $[6,7]$, meaning that heavier rainfall events are expected during winter and longer, more intense low-flow events may occur from May to late October.

Assessments of climate change impacts on regional hydrosystems are not sufficiently mature to be synergistically used with climate change adaptation decisionmaking [10, 11] designed to optimise what are called climate services [12]. These processes involve the full understanding of the regional system trajectory over decades or centuries. These approaches usually only consider the trajectory from now to tomorrow. At the Seine basin scale, the PIREN-Seine research programme promotes the study of trajectories from the past to today until tomorrow. This attempt to map the hydrosystem trajectory is the goal of this chapter. We believe that switching the cognitive reference from today to yesterday provides a broader view of the combined functioning of the anthro-eco-hydrosystem and it makes complete sense to evaluate climate services and possible adaptation strategies in a "safe operating space" [13]. 
Rebuilding a past trajectory involves the reconstruction of both past climate and past land use. Data assimilation in global circulation models was proposed in the 1990s and allowed the reanalysis of meteorological data over 40 years [14], which has led, in the 2010s, to multiple decade-long climate reanalysis [15-17] and also century-long reanalysis [18, 19]. Bonnet et al. [20] leveraged on those century-long reanalyses by downscaling them at the Seine basin scale. In the continuity of this work, a first reconstruction of the past hydrological trajectory of the Seine basin was proposed by Bonnet [21]. However, the Anthropocene era [22, 23] also introduced major land use changes over the past century [24-26], which we will account for in our attempt to rebuild the hydrosystem trajectory since the early 1900 s.

This work is the accomplishment of 30 years of hydrogeological studies on the Seine basin within the PIREN-Seine programme. Starting from local studies at the river-aquifer interface [27, 28] and the knowledge on deep long-term water circulations in the Paris basin aquifer system [29-32], a first coupled hydrologicalhydrogeological model of the Seine basin was proposed by Gomez et al. [33] and further enhanced for the simulation of surface-subsurface interactions [34, 35]. This modelling tool spread in the hydrometeorological community inspiriting global circulation models [36] and initiating combinations with soil-vegetation-atmosphere-transfer models [9, 37, 38]. It was also used for various combined applications to study the trajectory of nitrate due to agricultural practices [39-41] as well as the impact of climate change on water quality [42]. All these studies led to the distributed process-based hydrological-hydrogeological model CaWaQS [43-45] that is used in this anniversary chapter on the trajectory of the Seine basin water resources.

\section{Historical Records of the Seine River Discharge in Paris}

The Pont d'Austerlitz gauging station offers the longest and most viable mean daily discharge time series for the Seine River. The first estimates of discharge go back to 1885. At this station, the Seine River drains an area of $43,800 \mathrm{~km}^{2}$, which corresponds to $60 \%$ of the total basin. Hence, this data set provides a valuable glimpse into the large-scale hydrological functioning of a significant part of the basin. It also bears remarkable traces of the long-term evolution of environmental factors that influence flow dynamics, whether natural or human-induced. Furthermore, the Austerlitz discharge data provide the opportunity to analyse the response of the basin to historical extreme events (floods and droughts).

Overall, the Seine reaches high-flow conditions in mid-February with a multiannual average flow rate of $583 \mathrm{~m}^{3} \mathrm{~s}^{-1}$ and smoothly arrives at low-flow periods in August with an average rate of $125 \mathrm{~m}^{3} \mathrm{~s}^{-1}$ (Fig. 1a). Yet, the interannual variability of flow is remarkably high, especially between wet periods where the difference between the 0.95 and 0.05 quantiles is on the order of $1,000 \mathrm{~m}^{3} \mathrm{~s}^{-1}$. This is also reflected in historical extrema: discharge records range from a minimum $20 \mathrm{~m}^{3} \mathrm{~s}^{-1}$ (historical drought of 1921) to over a maximum 2,600 $\mathrm{m}^{3} \mathrm{~s}^{-1}$ (historical flood of 

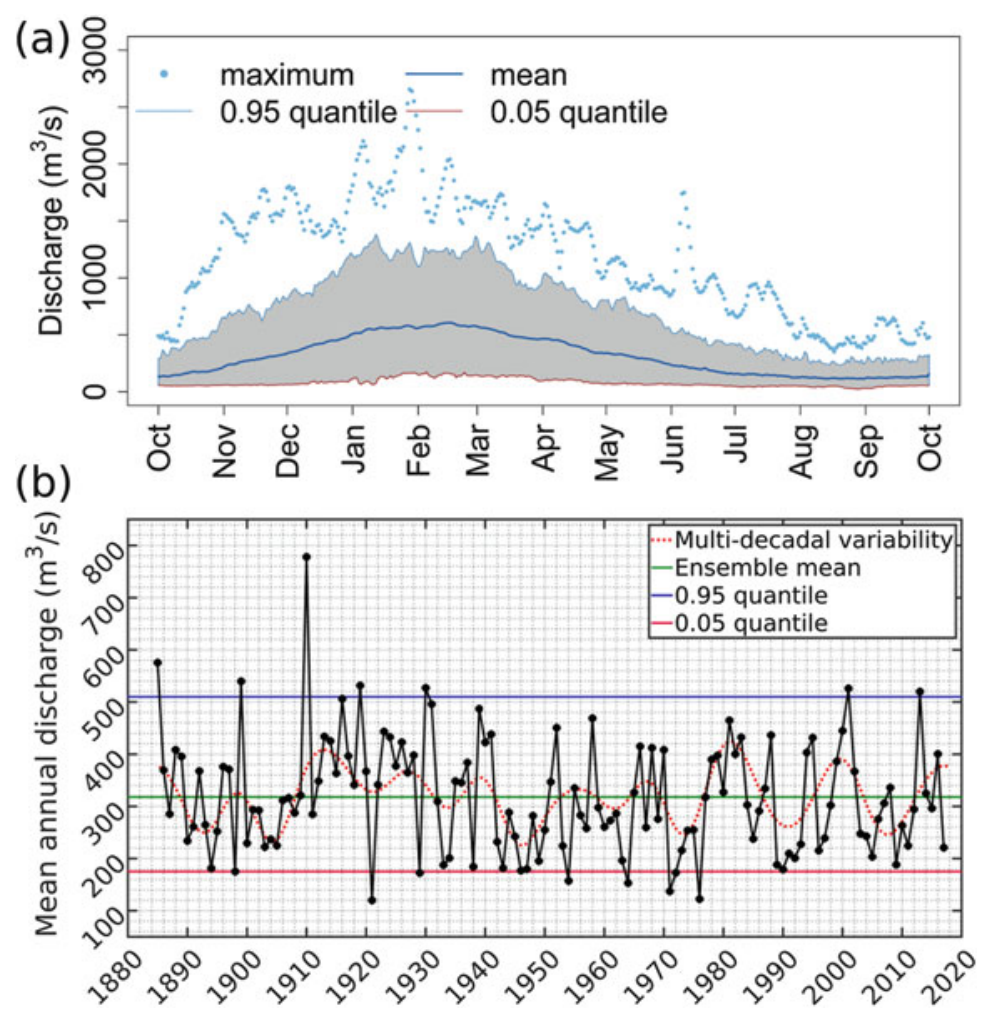

Fig. 1 Seine discharge estimates from water levels at the Pont d'Austerlitz (Paris) gauging station since 1885. (a) Mean and maximum daily discharge over the hydrological year. The 5th and 95th quantiles are also displayed. Calculation based on the R package FlowScreen [46]. (b) Mean annual discharge (black dots and black solid line) and multi-decadal variability (dashed red line) obtained by summation of the last 3 details out of 14 from the discrete wavelet transform of mean daily discharge, using an order 4 Symlet mother wavelet

1910) (Fig. 2a). Hence, the discharge rates at Pont d'Austerlitz vary within two orders of magnitude.

In addition to the strong interannual variability, the Seine is influenced by clear interdecadal variability (Fig. 1b). Indeed, the long-term average discharge measured at Pont d'Austerlitz between 1885 and 2018 is $319 \mathrm{~m}^{3} \mathrm{~s}^{-1}$, but mean annual flow rates typically range from $125 \mathrm{~m}^{3} \mathrm{~s}^{-1}$ to over $750 \mathrm{~m}^{3} \mathrm{~s}^{-1}$. In general, above and below average years tend to follow each other, and the succession of drier and wetter decades follows a distinguishable low-frequency pseudo-cyclicity (Fig. 1b). Such multi-decadal variability stems from known global-scale climatic and oceanic fluctuations, mainly the North Atlantic Oscillation (NAO) and the Atlantic Multidecadal Variability (AMV) [47-52]. The NAO index is defined by anomalies in the normalised atmospheric pressure difference between Reykjavik (Iceland) and Lisbon (Portugal) [48]. During positive NAO phases, strong anticyclonic conditions 


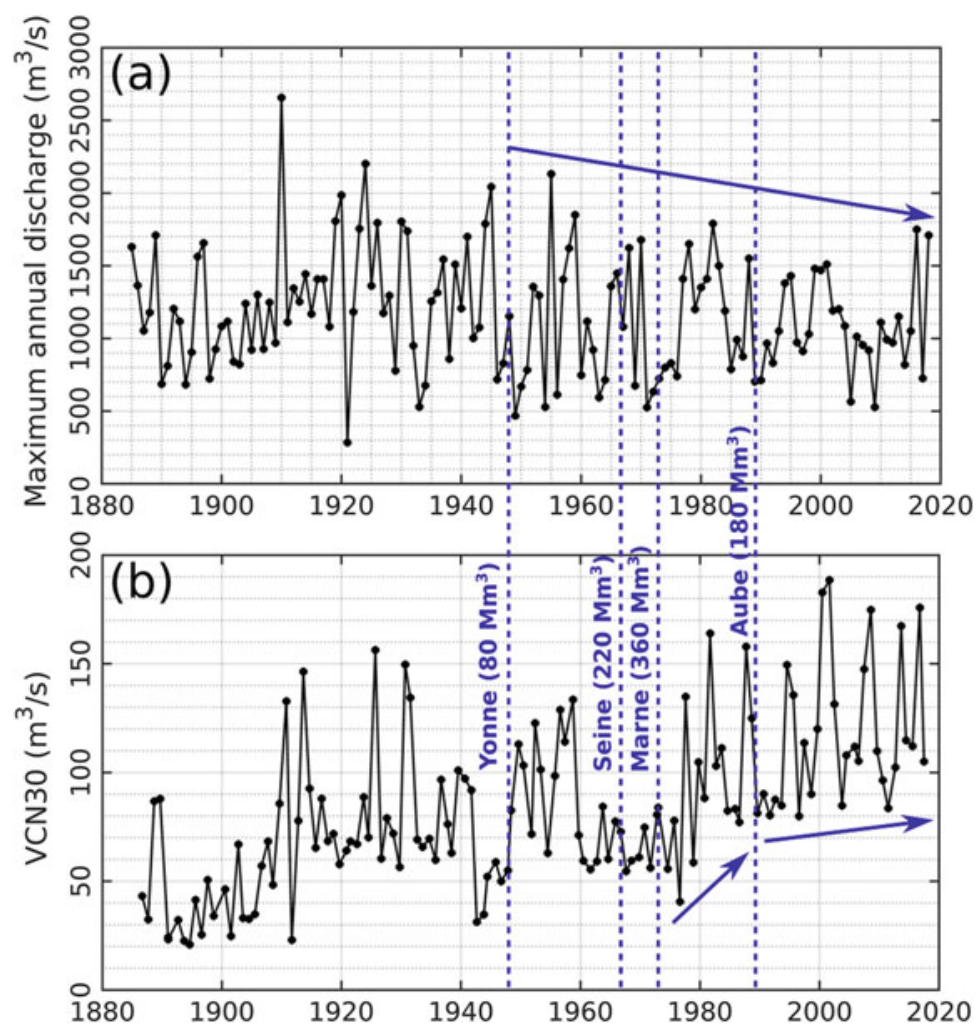

Fig. 2 Two statistical features of the Seine discharge data recorded at the Pont d'Austerlitz (Paris, France) gauging station since 1885. (a) Maximum annual discharge. (b) VCN30, defined as the annual minimum of a 30-day running average of daily mean discharge. The vertical dashed lines mark the commissioning of reservoir lakes in derivation of the Seine and its main tributaries upstream from Paris (names of the rivers are shown along with the reservoir volumes in millions of cubic metres, $\mathrm{Mm}^{3}$ )

prevail over the Azores, so that humid air masses are driven towards the north of Europe, where winters typically become wet and mild [53-55]. Hence, drier conditions over the Seine basin are encountered during negative NAO phases. The mechanisms driving the AMV are more controversial, since there is evidence for both natural and anthropogenic controls on its variability. Nevertheless, the role of Atlantic buoyancy-driven circulation on the AMV is generally recognised as predominant (see [47] and reference therein). In terms of a temporal signature, the NAO's periodicity mainly lies within two bands, 5-7 years and 16-19 years, whereas the AMV is characterised by timescales varying between 60 and 100 years [21, 47, 52, 56, 57], which makes it more difficult to detect given the relative shortness of the available records $[52,58]$. These global-scale climatic processes were proven to be largely responsible for the Seine's observed variability in mean annual discharge $[47,50,59,60]$. 
Despite the presence of clear interannual and interdecadal variability throughout the discharge records, the most extreme flood events all occurred before the 1960s. Only in 1910, 1924, 1945 and 1955 did the maximum flow rates at Pont d'Austerlitz reach over 2,000 $\mathrm{m}^{3} \mathrm{~s}^{-1}$ (Fig. 2a). This is partly due to the creation and commissioning, since the mid-1960s, of large-capacity reservoirs upstream from the highly urbanised and populated Paris region [1]. The three largest reservoirs were built in derivation of the Seine in $1966\left(220 \mathrm{Mm}^{3}\right.$ capacity), the Marne in $1974\left(360 \mathrm{Mm}^{3}\right)$ and the Aube in $1990\left(180 \mathrm{Mm}^{3}\right)$. A smaller reservoir $\left(80 \mathrm{Mm}^{3}\right)$ was created in 1949 , but since it is located far upstream of the Yonne watershed, its impact on extreme events observed in Paris is less pronounced than the impact of the others. Until now, these reservoirs have successfully limited the impact of potentially damaging flood events by storing up to $840 \mathrm{Mm}^{3}$ of water. Alternatively, in the summer and during particularly dry periods, they release water to maintain a minimal target flow rate of $60 \mathrm{~m}^{3} \mathrm{~s}^{-1}$ in the Seine through Paris. This human-induced perturbation of the Seine's hydrodynamic functioning is noticeable in discharge data in at least two ways. First, the variance of mean and maximum annual discharges has decreased since the creation of the reservoirs (Figs. 1b and 2a). This demonstrates the ability to reduce the impact of climatic extremes on river flow by smoothing the flow signal, that is to say, by distributing rainfall inputs over time more efficiently than in natural (undisturbed) conditions. Second, the VCN30 values, the yearly minima of 30-day running average windows [61], have never dropped below $55 \mathrm{~m}^{3} \mathrm{~s}^{-1}$ since the beginning of the 1960s. The only exception occurred in 1976 during an extreme drought (VCN30, $40 \mathrm{~m}^{3} \mathrm{~s}^{-1}$, Fig. 2b) concomitantly with an extreme dry year (annual discharge, $120 \mathrm{~m}^{3} \mathrm{~s}^{-1}$, Fig. 1b). Furthermore, the VCN30 has only rarely dropped below $80 \mathrm{~m}^{3} \mathrm{~s}^{-1}$ since the beginning of the 1980s (Fig. 2b). This shows that the reservoirs considerably helped to mitigate the risk of extended low-flow periods, which may alter the integrity of river ecological habitats, as well as human activities.

The long discharge records at Pont d'Austerlitz hold valuable information on the overall dynamical response of the Seine hydrosystem to climatic inputs. Like any other hydrosystem on Earth, the Seine acts as a low-pass filter of effective precipitation, meaning that the highest frequencies in the climatic input signal are transformed by the various flow processes, whereas the lowest frequencies (typically, the interdecadal fluctuations) are generally transcribed exactly as they are into the discharge signal. From spectral analysis of effective precipitation and discharge data, it is possible to obtain a first-order estimate of the mean flow response time of the three fundamental compartments of a hydrosystem: the surface, the unsaturated layer and the aquifer [62]. When applied to the Austerlitz data since 1885, we estimate that the mean response times to climatic events are $1.7 \pm 0.2$ days, $5.0 \pm 1.3$ days and $2.5 \pm 0.2$ years for surface runoff, vadose zone flow and aquifer flow, respectively. Moreover, from the same analysis, we estimate that $81 \%( \pm 2)$ of the long-term river flow is sustained by groundwater. Unsurprisingly, this preliminary analysis shows that the Seine is largely dependent on groundwater stocks, which are very capacitive and transmissive given the sedimentary nature of the basin. It also shows that the Seine is highly vulnerable to extreme events, especially floods, given that the response time of the runoff component is short. Nevertheless, 
as reservoir lakes have altered the natural functioning of the basin since the mid-1970s, the apparent aquifer response time increases to $7.3 \pm 0.2$ years, and the fraction of groundwater supply to fluvial systems appears to be about $90 \%$ when the spectral analysis of discharge [62] is applied to data between 1974 and 2018. It makes sense that, somehow, the capacitive component of the system is perceived by simple interpretation tools to have a higher dampening effect, and a slightly higher contribution to total fluxes, in the presence of reservoirs. However, it is not possible to attribute this effect to subsurface property changes at this time scale, as it is conceptualised by these tools [62]. This demonstrates once more the sensitivity of river flow dynamics to territory developments, but it also shows the necessity of adopting more complex theoretical and modelling schemes to precisely understand, quantify and predict flow paths and processes throughout the basin, which is the exact purpose of this chapter.

\section{Development of the Seine Basin Model}

\subsection{CaWaQS Model}

The functioning of the Seine hydrosystem is nowadays simulated with CaWaQS (CAtchment WAter Quality Simulator) [43-45, 62, 63]. It is a spatially distributed model which simulates the water balance and dynamics of water flow in all compartments of a hydrosystem based on the blueprint published by de Marsily et al. [64] and first implemented as the MODCOU model [65-67]. A first attempt of reprogramming in Fortran90 was achieved with the EauDyssée project [34, 35, 6871], which mostly accounted for river stage fluctuations [34, 35, 69]. Following the extension by Flipo et al. [72] of the nested groundwater flow concept [73] in the stream-aquifer interface, CaWaQS 2.x was recoded [45] combining multiple $\mathrm{C}$ libraries. Running at a daily time step, calculations of surface, subsurface and groundwater flows are structured around five main components [45, 68]:

- A surface module, mainly conditioned by land use, climate and parent soil materials, which calculates the surface water balance via a conceptual reservoirbased approach [74, 75] using rainfall and potential evapotranspiration (PET) data to estimate actual evapotranspiration (AET), runoff and infiltration fluxes on each surface layer cell.

- An unsaturated module, which transfers water infiltration from the subsurface to the water table using a set of reservoirs so that the infiltration is diffused in time to form the aquifer recharge [76, 77].

- A saturated module that solves the pseudo 3D-diffusivity equation [78] in a multilayer aquifer system with a finite volume numerical scheme that uses water recharge as well as water withdrawals as forcings.

- A conductance model that represents surface-subsurface water exchanges $[72,79,80]$. 
- A hydraulic module that routes in-stream water flows using a Muskingum scheme [81, 82], from which water levels are derived using rating curves [34] or a manning approximation of a steady state [35, 69]. Computed discharges in each river cell of the hydrographic network result from both stream-aquifer fluxes and contributions from subsurface runoff.

\subsection{Implementation of the Seine Basin Model}

The surface layer of the model [45] covers an area of $81,200 \mathrm{~km}^{2}$ including the entire $76,300-\mathrm{km}^{2}$ Seine basin. The grid is divided into elementary watersheds of an average area of $11 \mathrm{~km}^{2}$, on which the surface water balance is calculated. The river network implemented in the model is directly provided by the Carthage national database ${ }^{1}$. In this application, both discharges and stream-aquifer exchange calculations are restricted to the main river network (Fig. 6) describing 4,520 km of rivers from Strahler orders 3-8 [83] at the mouth of the Seine River. While the first implementation of the model described three aquifer units [33, 39], the aquifer system was refined up to six aquifer units by Pryet et al. [35]. The current version, developed by Labarthe [45], discretises the multilayered structure in seven aquifer units, including alluvial plains, using a progressive multi-scale grid of nested square meshes, with cells varying from $200 \mathrm{~m}$ to $3,200 \mathrm{~m}$ in size. The seven aquifer units can be regrouped, from the oldest to the most recent, in three main ensembles [1]:

- A Cretaceous chalk aquifer that has by far the largest impluvium

- A five-layer Tertiary complex ensemble, located in the centre of the basin, covering aquifer units mainly made of limestones and sands, dating from Palaeocene to Miocene

- Quaternary alluvial deposits surrounding the basin's main rivers

Jurassic aquifers, which outcrop at the eastern border of the basin, are not represented as explicit aquifer layers and are treated by a subsurface procedure using a simplified reservoir model in order to route infiltration fluxes towards the hydraulic network.

\section{Current State of the Seine Hydrosystem}

A 17-year periodicity associated with the NAO was previously identified [50] on observed climatic and stream discharge data over the Seine basin. Both groundwater and river water storage have also been proved to be stationary over a 17-year period

\footnotetext{
${ }^{1}$ http://www.sandre.eaufrance.fr.
} 
[68]. All further results are therefore averaged over the 1993-2010 period to ensure their significance [84].

The model uses daily rainfall and PET provided by SAFRAN [85, 86], a mesoscale atmospheric analysis system for surface variables, producing data at a daily time step on an $8 \times 8-\mathrm{km}$ grid. SAFRAN uses the Météo-France observation network and data from a number of well-instrumented stations. The anthropogenic pressure on water resources is taken into account by means of water withdrawals in each aquifer unit. The yearly amount of each uptake is provided by the SeineNormandie Water Agency.

\subsection{General Two-Step Calibration Strategy of Hydrosystem Models}

Flipo et al. [68] proposed a stepwise calibration procedure for hydrosystem models. This method is further developed here in the form of an innovative two-step calibration methodology (Fig. 3) applied to the Seine basin [45]. The first step consists in the calibration of surface parameters with a process-based multi-objective function, which accounts for cumulative total river discharge and runoff dynamics. The estimation of the runoff dynamics is based on a proper hydrograph separation. Further details on the first step are given below. In the second step, subsurface

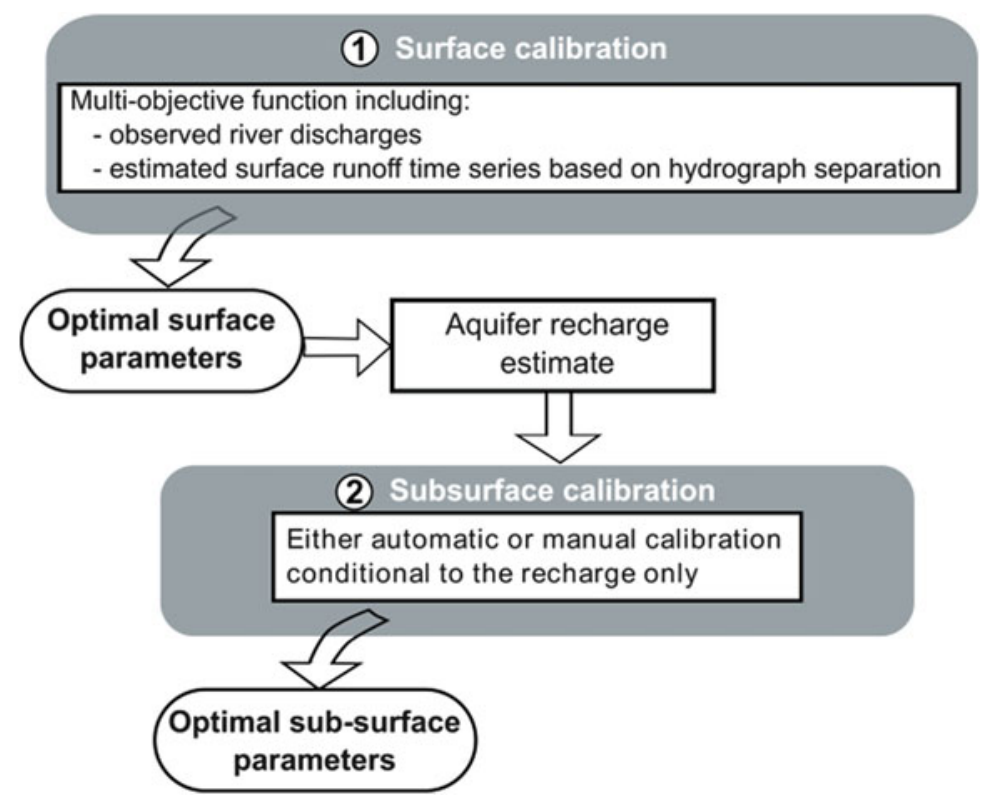

Fig. 3 Innovative two-step calibration procedure of the Seine basin with the CaWaQS model. The outcome of each step is an optimal parameter set (bold case) 
parameters are calibrated given the infiltration rate calculated at the end of the first step. For this step, a classical trial-and-error method is used [35]. The conductance coefficient is automatically calibrated [35] using the horizontal permeability of the aquifer near the river to calculate the conductance at each river cell [79].

The first step is crucial in our approach, since the second step is conditional to the aquifer recharge estimated by the first step. Hydrosystem internal water fluxes estimated by surface-subsurface-coupled models are highly sensitive to recharge estimation [87], and subsurface parameters are highly sensitive to baseflow estimates $[88,89]$, which are correlated with aquifer recharge [90, 91]. Taking into account these crucial considerations, the core idea of our method is to add a baseflow estimate to the classical measurements (total river discharge and groundwater levels) that compose the multi-objective function to be minimised. Baseflow estimations were calculated directly from observed discharge time series, distributed in 30 gauging stations across the Seine basin [45], with the one parameter recursive digital filter first proposed by Lyne and Hollick [92] and later improved by Chapman [93]. Hydrograph separation is based on the estimation of the recession parameter, which is achieved by fitting the slope of $\log Q(t)$ after rainfall events [94].

River discharges are simulated properly by the CaWaQS model over 1993-2010 at various stations of the basin (Table 3). For instance, the Nash Efficiency [95] at the Paris Austerlitz station reaches 0.9 [45].

\subsection{Average Water Budget 1993-2010}

The basin is submitted to an average annual precipitation rate of $812 \mathrm{~mm} \mathrm{a}^{-1}$ and exhibits a large spatial variability according to both distance from the ocean and elevation, ranging from 595 to $1,370 \mathrm{~mm} \mathrm{a}^{-1}$ (Fig. 4a).

The infiltration rate amounts to $111 \mathrm{~mm} \mathrm{a}^{-1}$ over the whole basin, corresponding to $56 \%$ of the effective rainfall (Fig. 5). In coherence with the spatial distribution of rainfall, a centripetal gradient is observed, ranging from $181 \mathrm{~mm} \mathrm{a}^{-1}$ on the eastern Jurassic border to $82 \mathrm{~mm} \mathrm{a}^{-1}$ over the central part of the basin, where an aquifer system is explicitly simulated (Fig. 4c). Groundwater withdrawals account for $14 \%$ of the total aquifer system recharge, of which $21 \%$ is provided by infiltration from rivers (Fig. 5).

Within the multilayer aquifer system, a dominant downward vertical flux from the subsurface to the deep chalk aquifer is simulated, $44 \%$ of which is redistributed to the alluvial deposits in the outer portions of the basin (Fig. 5). Supply from aquifers to rivers appears to be the dominant flow direction along the modelled streamaquifer interface (Fig. 6); an exfiltration rate of $140 \mathrm{~m}^{3} \mathrm{~s}^{-1}$ from aquifers supplies the river network, while $47 \mathrm{~m}^{3} \mathrm{~s}^{-1}$ infiltrates the other way around (Fig. 5). On average the river network drains $10 \mathrm{~L}^{-1} \mathrm{~s}^{-1} \mathrm{~km}^{-1}$ from the aquifer system [35, 45].

The proportion of the river network that is in a gaining configuration reaches $82 \%$ and would rise to $97 \%$ if all water withdrawals in the aquifer system were stopped. The surface-subsurface functioning is thus significantly altered by the 

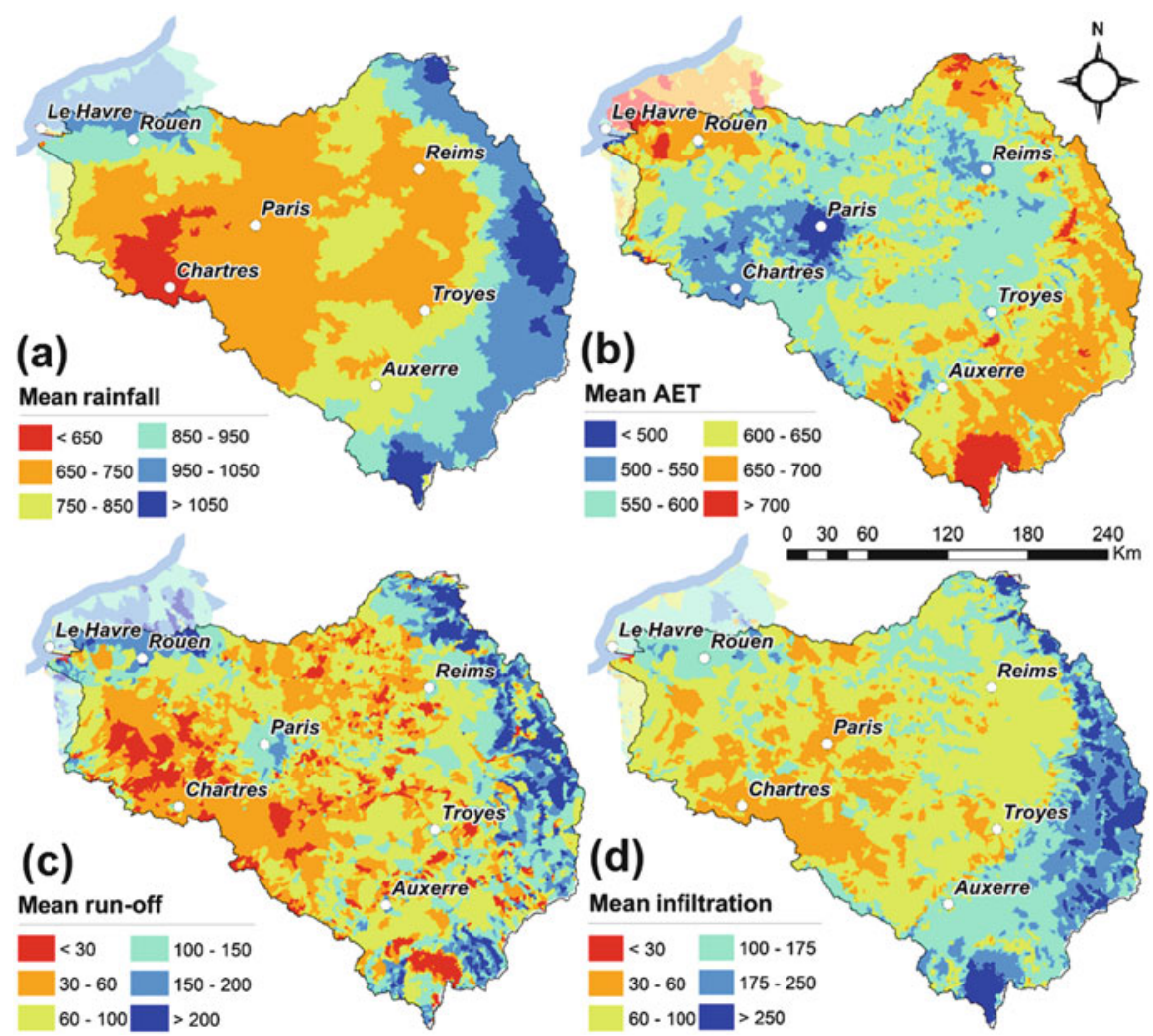

Fig. 4 Averaged spatial distributions over the 1993-2010 period of (a) SAFRAN annual rainfall and simulated, (b) annual AET, (c) annual infiltration, (d) annual runoff. Units in $\mathrm{mm} \mathrm{a}^{-1}$

anthropogenic pressure on the groundwater resources, which in turn modifies the biogeochemical functioning of the interface and greenhouse gas emissions [96]. The consequences of such alterations on river ecology are still poorly understood and are the focus of ongoing research [97, 98]. Heavy pumping removes $10 \mathrm{~m}^{3} \mathrm{~s}^{-1}$ from alluvial plains connected to the downstream part of the river network (Strahler orders $>3$ ). Half of it is taken up from the alluvial aquifers, and the other half is taken directly from rivers through the natural upward motion of the water from the aquifer to the river [35].

At the river-aquifer interface, water is exchanged upward and downward. The absolute summation of these two is called "gross flux", while the difference is called "net flux". At the Seine basin scale, the gross flux is $50 \%$ larger than the net flux. During dry years, those proportions remain unchanged, while they increase by $50 \%$ during wet years [35].

As conceptualised by Flipo et al. [72], most of the water exchanges along the main river network take place in the stream-aquifer interface represented at this scale 
N. Flipo et al.

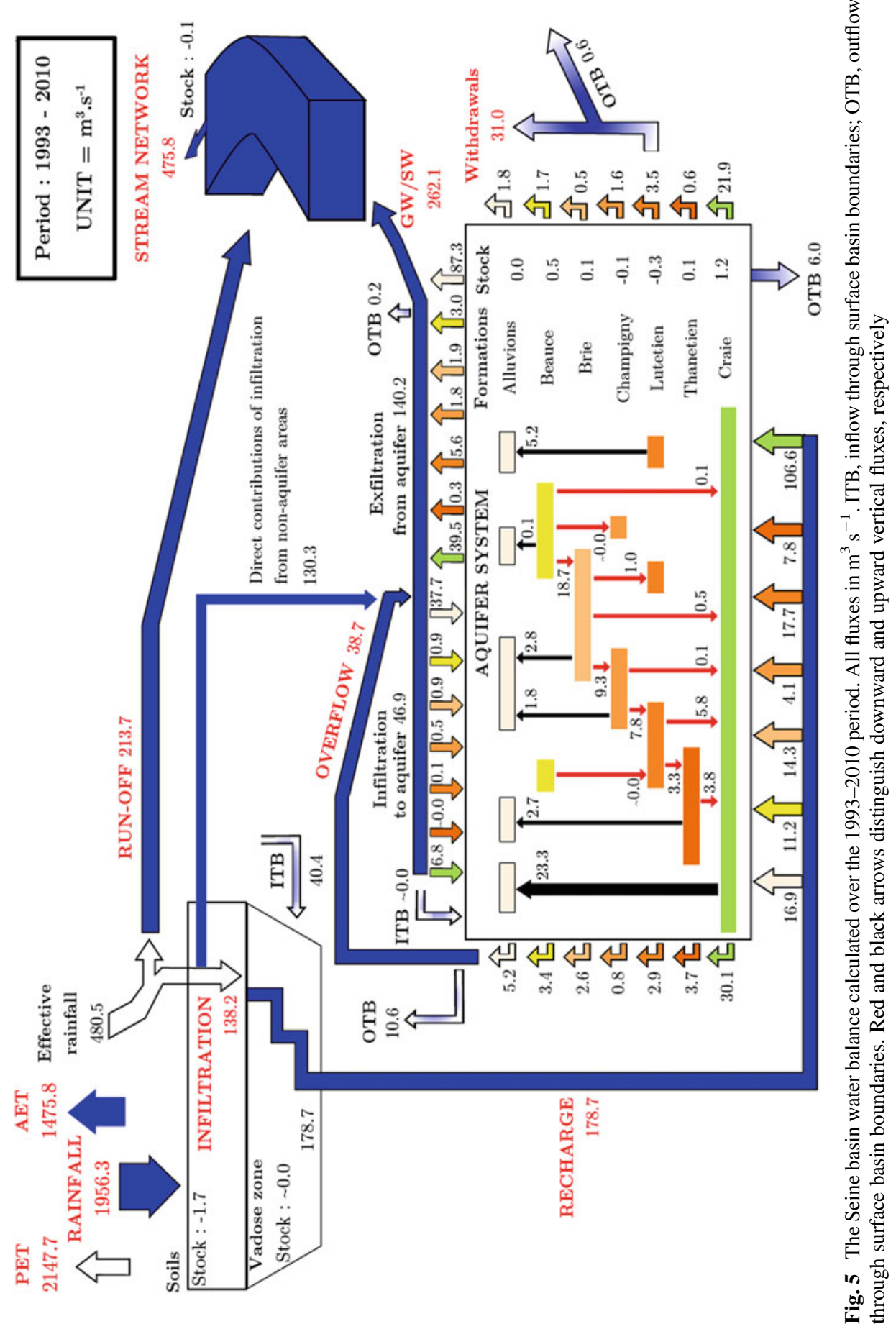




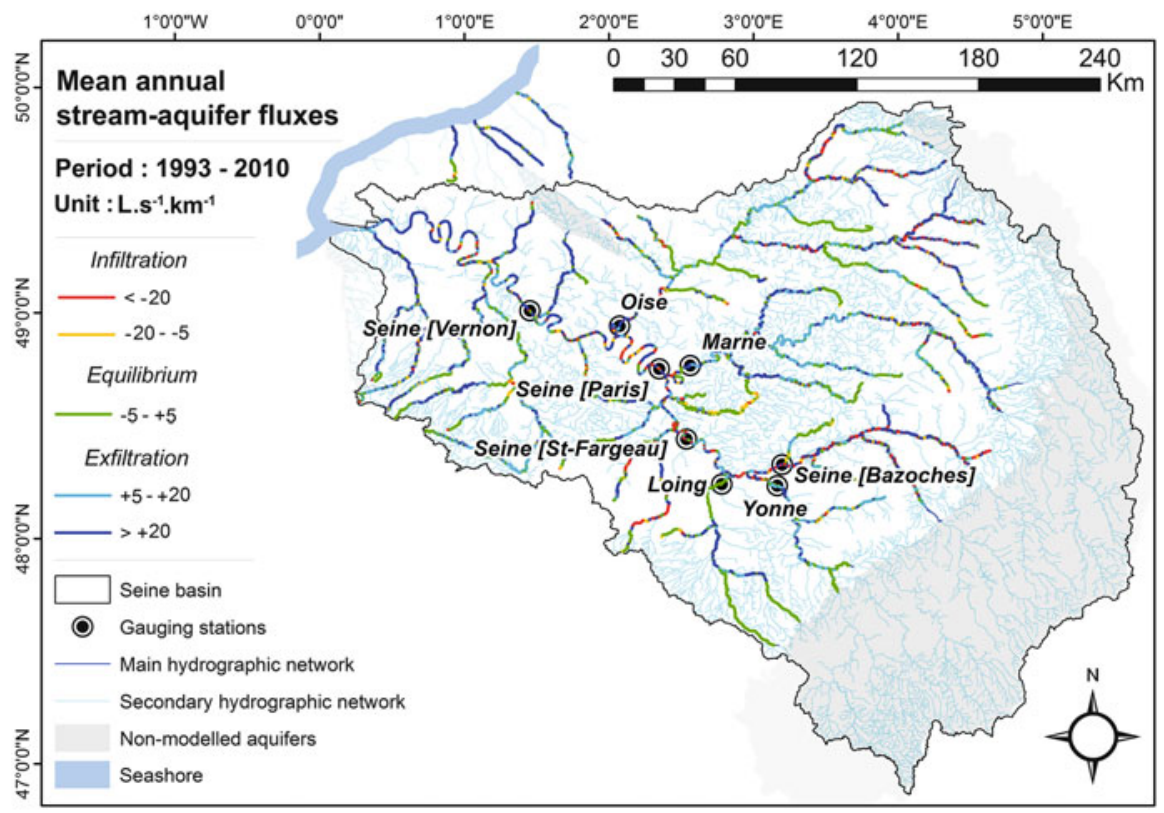

Fig. 6 Spatial distribution of stream-aquifer exchanges averaged over the 1993-2010 period. The main gauging stations of the basin are also displayed

by the alluvial plains. Overflows as well as direct exchanges at the stream-aquifer interface from aquifers contribute $55 \%$ of the river network discharge at the basin outlet (Fig. 5).

\section{A Two-Century-Long Trajectory of the Seine Basin}

The model provides the opportunity to characterise modifications in behaviour of the Seine hydrosystem under different scenarios combining preselected constraints on climate, land use and anthropogenic pressure data. It is therefore possible to reconstruct the trajectory of the system from the early 1900s to the end of the current century. Two scenarios are proposed to re-evaluate water fluxes: (1) a simulation associated with the first part of the twentieth century (1917-1934), which integrates past daily climate data as well as modifications in the surface distribution of land use, and (2) a second one (2083-2100) using climate data derived from a general circulation model (GCM) forced by the high emission scenario RCP8.5 [5] to evaluate the response of the Seine system in a context of climate change. Radiative forcings in RCP8.5 increase throughout the twenty-first century before reaching a level of $8.5 \mathrm{~W} \mathrm{~m}^{-2}$ at the end of the century. Modifications in groundwater withdrawal rates are also implemented. For the sake of clarity, results from both 
Table 1 Key figures on distributions of land cover and withdrawal types in groundwater as well as population rates at the scale of the Seine basin for the 2000s simulation. Other values identify respective relative variations (\%) for the $1900 \mathrm{~s}$ and 2100 s scenarios when compared to the $2000 \mathrm{~s}$ reference

\begin{tabular}{l|l|l|l}
\hline Scenario & $1900 \mathrm{~s}$ & $2000 \mathrm{~s}$ & $2100 \mathrm{~s}$ \\
\hline \multicolumn{4}{|l}{} \\
Withdrawal types (in $\mathrm{Mm}^{3} \mathrm{a}^{-1}$ ) \\
\hline Drinking water & $-100 \%$ & 731 & $-12.9 \%$ \\
\hline Industrial processes & $-100 \%$ & 169 & $-52.6 \%$ \\
\hline Irrigation & $-100 \%$ & 96 & $-2.5 \%$ \\
\hline Total & $-100 \%$ & 996 & $-16.7 \%$ \\
\hline Land use (in \% of the surface domain) \\
\hline Urban areas & $-3.3 \%$ & 7.9 & $+0.1 \%$ \\
\hline Forested lands & $-2.7 \%$ & 23.2 & $0 \%$ \\
\hline Agricultural lands & $+6.0 \%$ & 68.9 & $-0.1 \%$ \\
\hline Demography (in $10^{6}$ inhabitants) & & \\
\hline Population rate & $-47 \%$ & 16.7 & $+26 \%$ \\
\hline
\end{tabular}

simulations will be referred to as " 1900 s" and " 2100 s" in the remainder of the paper. Results from the SAFRAN reference simulation will be referred to as " 2000 s" or "reference situation".

\subsection{Estimating Land Cover Changes}

The land cover and soil texture define the hydrological response unit on which the water balance is calculated. A crucial step for the simulation of scenarios is therefore to estimate the changes in the land cover for the three main types of land use: urban areas, agricultural lands and forested lands (Table 1).

At the scale of all 24 administrative districts of the basin, 1901 and 2009 population census data provided by the National Institute of Statistics and Economic Studies (INSEE ${ }^{2}$ ) have allowed evaluating urban areas for the 1900s scenario, using equation (1), which relates the surface of artificialised area $S_{a}$ (in hectares for $10^{3}$ inhabitants) and the population density $p$ (in inhabitants $/ \mathrm{km}^{2}$ ) [99]:

$$
S_{a}=1,475 p^{-0.6}
$$

In the case of the 2100s run, a similar method was implemented using results from the Explore 2070 project [100], which provides projection data on how the population is expected to evolve by the year 2070. This was considered steady until the year 2100.

Regarding forested areas, data between 1950 and 2010, also provided at the administrative district scale, were extracted from the annual agricultural statistics

\footnotetext{
${ }^{2}$ https://www.insee.fr/en/accueil.
} 
data sets [101] for the 1900s scenario. However, no raw data are available before 1950. Thus, these spatial distributions were considered to be steady over the 1900-1950 period, given its negligible variation during the first half of the twentieth century [102]. Forested areas were also considered steady in the 2100s scenario when compared to the present day.

Then, in the 1900s scenario only, land use was refined over the Paris area [1] using data made available by the Urbanism and Land Use Institute for the Île-deFrance area $\left(\mathrm{IAU}^{3}\right)$. This additional step tends to integrate, as precisely as possible, the significant extension of the urban area over time and its consequences on local water budget calculations. In both cases, forested and urban area adjustments were made at the expense or benefit of the proportion of agricultural lands over the entire domain. These modifications were made assuming no significant changes in wetlands areas.

\subsection{Estimating Anthropogenic Water Uptake}

Projections from the Explore 2070 project [100] allowed integrating variation coefficients on present pumping rates in groundwater into the prospective 2100 s simulation. These coefficients have been differentiated according to pumping types and geographical location (data not shown). These projections, which were elaborated in conjunction with demographic growth hypotheses and population migration processes, are based on extension of INSEE forecasts, i.e. the overall population rate of the basin to over 21 million inhabitants in 2070 (Table 1). Regarding drinking water withdrawals, forecasts expect a $40 \%$ increase in the number of households over the 2006-2070 period along with a decrease in water consumption, which has been differentiated according to the habitat type $(-0.3 \%$ per year for buildings, $-0.6 \%$ per year for private housing). A slight improvement in supply system efficiency is also integrated $(+0.2 \%$ per year). Three main variables are involved in hypotheses on industrial-related withdrawals: production rate, past observed trends in water savings and types of cooling circuits. These forecasts are based on a general $4.0 \%$ decrease in water withdrawals per year, partly compensated with an increase in industrial production. They also emphasise the pursuit of cooling circuit closures along continuous improvements in water use efficiency of production processes. Finally, irrigation requirements are calculated according to crop types, integrating plant water demand, rainfall over agricultural lands as well as water efficiency of irrigation techniques (gravity-fed or drip irrigation). It remains important to bear in mind that these projections do not account for any impact of climate change, especially in the case of seasonal pumpings.

To summarise, the implementation of the Explore 2070 projections resulted in a decrease of the total volume withdrawn of $16.7 \%$ with ranges of variation of -2.5 ,

${ }^{3}$ https://en.iau-idf.fr/. 
-12.9 and $-52.6 \%$ for irrigation, drinking water and industrial processes, respectively (Table 1). Current groundwater total uptake is $996 \mathrm{Mm}^{3} \mathrm{a}^{-1}$, divided into $73 \%, 17 \%$ and $10 \%$ for drinking water, industrial processes and irrigation, respectively. Regarding the 1900s simulation, the assumption is made that most of the withdrawals were taken from surface water in the early twentieth century. For this simulation, there are no groundwater withdrawals.

\subsection{Climate Scenarios}

\subsubsection{Reanalysis of the Past}

The 1900s scenario climate variables are described using newly materialised reconstructions over long-term atmospheric reanalysis elaborated by Bonnet [21]. The reanalysis is based upon the twentieth-century NOAA 20CRv2c reanalysis [18], which was downscaled [20] following a statistical downscaling strategy [103, 104] that mobilises the ISBA-MODCOU chain $[38,105]$. These data, downscaled at the SAFRAN grid scale, integrate the use of homogenised observations in the process of statistical downscaling in order to ensure a correct reproduction of the spatiotemporal variability of precipitation, temperature and river flows.

\subsubsection{Selecting an Appropriate Climate Product for the Projection}

Many worldwide climatic reanalysis and prediction products exist. Owing to differences in model structure, parametrisation and regionalisation, these products generate dissimilar results for precipitation and potential evapotranspiration, which eventually lead to distinct hydrological predictions [104, 106-108]. More precisely, while hydrological parametrisation and regionalisation are of the utmost importance for the evaluation of hydrological functioning at the seasonal scale, climate modellers agree on the fact that climate models are the dominant source of uncertainty in future climate projection [106-108]. To evaluate the impact of climate change on regional hydrosystems, various approaches are used [109], mostly based on statistical downscaling $[6,104,109]$ or the use of a regional climate model such as in the EUROCORDEX initiative [110]. To analyse the Seine hydrosystem trajectory in the future, we therefore decided to pay careful attention to the ability of the method to reproduce the current state of the system, as recommended by Radanovics et al. [111]. Projection data from four GCMs and one regional climate model from the Fifth Coupled Model Intercomparison Project (CMIP5) [5] were therefore disaggregated at the scale of SAFRAN grid and made available for the 1850-2100 period. Data from the following models were analysed: CanESM2 (Canada), MIROC5 (Japan), BCC-CSM-1-1-m (China), CSIRO-Mk3-6-0 (Australia) and Aladin-Climat (France).

As shown in Sect. 1.2, the hydrology of the Seine is responsive to long periods of climatic fluctuations due to large-scale climatic phenomena, such as the NAO. 
Consequently, it is important to establish the presence and consistency of such fluctuations in the climatic product that is used for hydrological simulations, especially given that low-frequency fluctuations are difficult to simulate [112]. Therefore, we applied wavelet transformation techniques to compare the five climatic precipitation products to the SAFRAN precipitation reanalysis in four different sectors of the Seine basin. The four sectors chosen, thought to be representative of different local hydroclimatic conditions, are Pays de Caux (NW), Beauce (S), Champagne (NE) and the Morvan plateau (SE). For each sector, we considered the daily precipitation average over three-by-three grid cells, hence covering a sample area of $576 \mathrm{~km}^{2}$. Time series of daily precipitation were transformed using a continuous wavelet transformation with a Morlet mother wavelet, in order to disentangle the various scales of variability in the signal (Fig. 7). Only the results for the Beauce
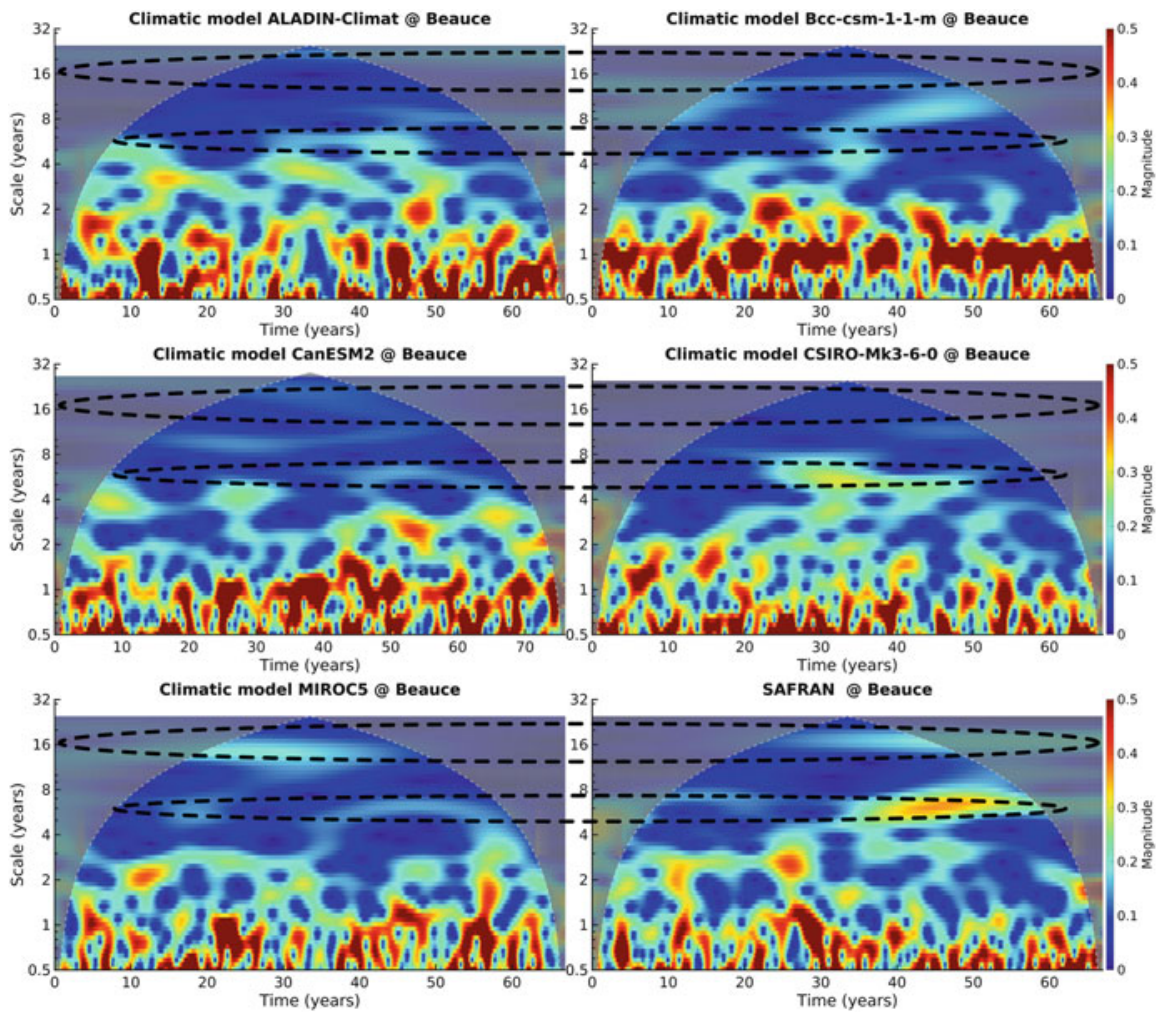

Fig. 7 Magnitude scalograms of daily precipitation time series in the Beauce sector of five climatic model products and for the SAFRAN data, used as the reference. The magnitude is set to a threshold of $0.5 \mathrm{~mm}$ in all scalograms in order to enhance visibility of low-frequency (high-scale) components. The MIROC5 model was chosen for hydrological simulation because the structure of its scalogram is the closest to SAFRAN's scalogram, especially concerning the 5-7- and 16-19-year scales. The white dashed line delimits the cone of influence, beyond which estimates of magnitude cannot be trusted 
sector are displayed; the other sectors did not display any fundamentally different result. From this analysis, it appears that all climatic models differ significantly from the SAFRAN reanalysis, which is not surprising given the well-known difficulty of climatic modelling and downscaling [104]. In particular, the BCC-CSM, CanESM2, CSIRO-Mk3 and Aladin-Climat models do not bear the appropriate scales of low-frequency variability. For instance, the low-frequency variability found in BCC-CSM does not have the same scales as in the SAFRAN reanalysis (i.e. the 5-7- and 16-19-year scales), and the magnitudes associated with the annual cycle are overestimated. The CSIRO-Mk3 and CanESM2 products fail to show any significant variability above the 10-year scale, which is inconsistent with observations [50, 59] (Fig. 7). In contrast, MIROC5 precipitation outputs generally entail the closest-matching scales of variability, even if a lack of energy can be noted for the 5-7-year scale, which is the case for all models. Therefore, MIROC5 was selected as input for hydrological forecasts of the 2100 s scenario to illustrate the potential changes in the hydrosystem functioning.

\subsection{Water Resources Trajectory from the 1900s to the 2100s}

How the Seine basin evolved from the 1900s to the 2100s was evaluated. For each case evaluated, the variations in fluxes are expressed according to a reference simulation under the assumption that the bias on climate forcings is stationary between the simulated and the reference periods. The reference simulations are either (1) the average state of the system previously simulated (2000s, Fig. 5) for the 1900 s scenario $^{4}$ or (2) the average simulated state using MIROC5 climate data over the same period, for the 2100 s scenario.

\subsubsection{Water Budget and Recharge Modes}

Like many other basins across western and northern Europe, the Seine discharge displays strong seasonality that is mainly driven by the quasi-sinusoidal fluctuation of the actual evapotranspiration throughout the hydrological year, whereas the precipitation input is much more stable over time in the reference simulation (Fig. 8). This growing seasonal gap in rainfall has an impact on the infiltration/ runoff partition rate, which can especially be observed on the 2100 s scenario. Indeed, despite a similar effective rainfall rate when compared to the 2000s simulation (Table 2), a relative variation in runoff of $+14.0 \%$ is simulated, along with a

\footnotetext{
${ }^{4}$ A proper comparison between the 1900 s and the 2000 s should consider the average hydrosystem state forced by Bonnet's meteorological forcings [21] rather than the SAFRAN reanalysis. However, a visual comparison between the two simulations shows that they are very close (data not shown). For readability the SAFRAN reanalysis is used in the remainder of the paper.
} 


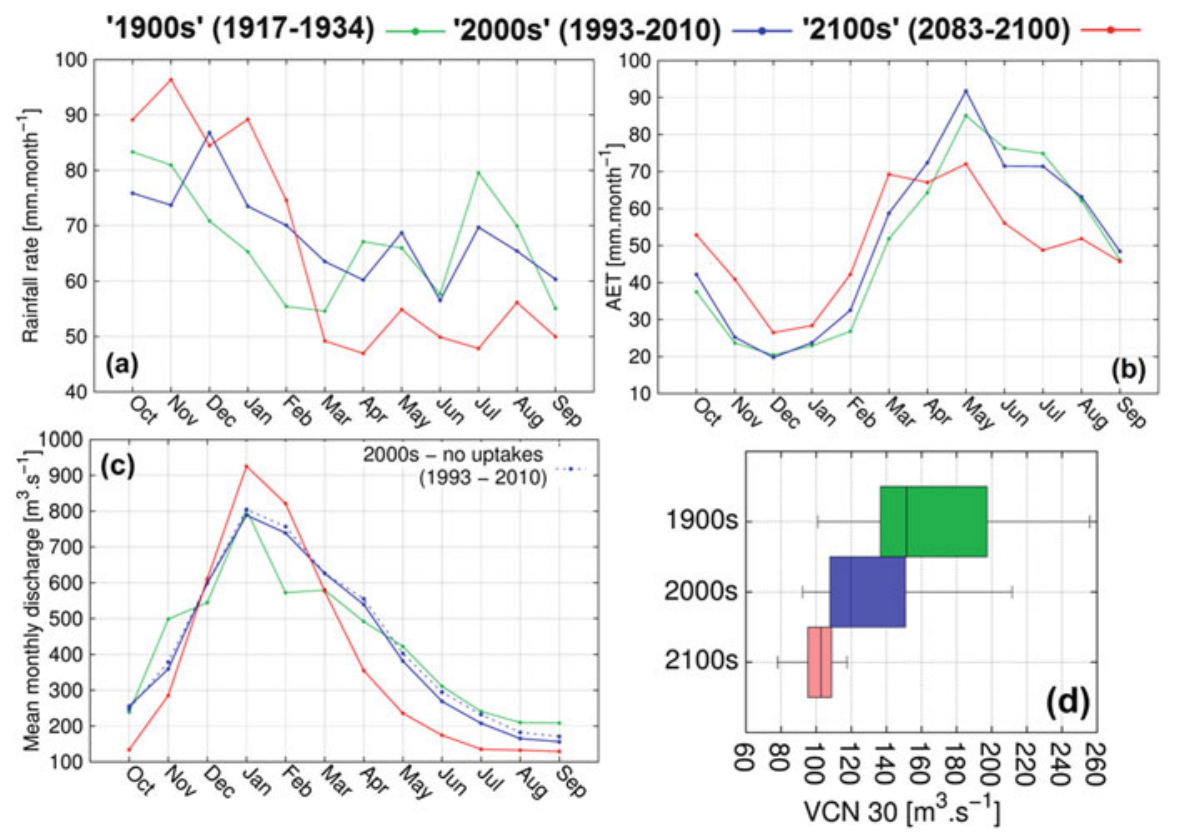

Fig. 8 Distribution of average monthly (a) rainfall rate $(\mathrm{mm})$ and (b) actual evapotranspiration rates $(\mathrm{mm})$ over the Seine basin; (c) monthly distribution of mean discharge $\left(\mathrm{m}^{3} \mathrm{~s}^{-1}\right)$ of the Seine River at the basin outlet (Seine at Vernon); (d) distribution of simulated annual minimum moving average over a 30-day period at the basin outlet. Blue, 2000s simulation forced with SAFRAN; green, 1900s simulation forced with Bonnet's reanalysis [21]; red, 2100s simulation forced with MIROC5

decrease of infiltration of $-6.0 \%$, which is due to spatio-temporal variations in the meteorological forcings (Fig. 9). To a lesser extent, a contrary observation could have been formulated for the 1900s, which is the result of both climate forcings and land use changes, particularly in the lower extent of the Paris urban area in the 1900s. In this case, it is not possible to disentangle the two origins based solely on these simulations.

Although the 2100s scenario is slightly drier in terms of recharge over the Seine basin (Table 2), recharge variation is not homogeneous spatially (Fig. 10b, d). Indeed, the lower Eocene and Palaeocene aquifer layers undergo a slight increase of recharge, $+3.0 \%$ and $+8.7 \%$, respectively. Negative variations are more pronounced further west over the Cenomanian aquifer $(-9.5 \%)$ and the eastern Jurassic border $(-8.6 \%)$. 
Table 2 Characterisation of the impact of the 1900s and 2100s scenarios on the behaviour of the Seine hydrosystem

\begin{tabular}{|c|c|c|c|c|c|c|c|}
\hline & Variable & $1900 \mathrm{~s}$ & $2000 \mathrm{~s}$ & RV & $\begin{array}{l}\text { CGM } \\
\text { ref. }\end{array}$ & $2100 \mathrm{~s}$ & RV \\
\hline \multirow{7}{*}{$\begin{array}{l}\text { Surface } \\
\text { domain } \\
\text { variables }\end{array}$} & Rainfall & $1,870.5$ & $1,956.3$ & -4.4 & $1,817.6$ & $1,850.7$ & +1.8 \\
\hline & PET & $1,916.1$ & $2,147.7$ & -10.8 & $1,943.1$ & $2,455.9$ & +26.4 \\
\hline & AET & $1,408.6$ & $1,475.8$ & -4.6 & $1,415.4$ & $1,437.6$ & +1.6 \\
\hline & Effective rainfall & 461.9 & 480.5 & -3.9 & 402.2 & 413 & +2.7 \\
\hline & Runoff & 178.7 & 213.7 & -16.4 & 170.8 & 194.6 & +14.0 \\
\hline & $\begin{array}{l}\text { Infiltration on } \\
\text { whole domain }\end{array}$ & 287 & 268.5 & +6.9 & 231.6 & 217.8 & -6.0 \\
\hline & $\begin{array}{l}\text { Infiltration on } \\
\text { non-aquifer areas }\end{array}$ & 144.4 & 130.3 & +10.8 & 121.3 & 110.8 & -8.7 \\
\hline \multirow{2}{*}{$\begin{array}{l}\text { Aquifer } \\
\text { system }\end{array}$} & GW recharge & 189.1 & 178.7 & +5.8 & 142.3 & 135.4 & -4.9 \\
\hline & GW uptakes & 0.00 & 31.6 & - & 31.6 & 26.3 & -16.8 \\
\hline \multirow[t]{7}{*}{$\begin{array}{l}\text { SW-GW } \\
\text { exchanges }\end{array}$} & $\begin{array}{l}\text { Infiltration from } \\
\text { SW to GW }\end{array}$ & 39.8 & 46.8 & -15.1 & 46.9 & 47.3 & +0.9 \\
\hline & $\begin{array}{l}\text { Overflows from } \\
\text { GW }\end{array}$ & 51.4 & 38.7 & +32.9 & 27.6 & 28.1 & +1.7 \\
\hline & $\begin{array}{l}\text { Exfiltration from } \\
\text { GW to SW }\end{array}$ & 160.9 & 140.2 & +14.8 & 123.5 & 124.9 & +1.1 \\
\hline & $\begin{array}{l}\text { Contribution from } \\
\text { GW to SW }\end{array}$ & 316.7 & 262.1 & +20.9 & 225.5 & 216.9 & -4.1 \\
\hline & Discharge at outlet & 495.6 & 475.8 & +4.2 & 396.3 & 411.1 & +3.7 \\
\hline & Infiltration length* & 615.9 & 794.7 & -22.5 & 935.4 & 907.3 & -3.0 \\
\hline & $\begin{array}{l}\text { Exfiltration } \\
\text { length* }\end{array}$ & $3,475.3$ & 3,314 & +4.9 & $3,146.9$ & $3,171.3$ & +0.8 \\
\hline
\end{tabular}

All relative variations (RV) are a \% expressed according to their respective reference. Main water fluxes calculated over 17-year periods in $\mathrm{m}^{3} \mathrm{~s}^{-1}$ except where noted * in kilometres. $G W$ groundwater, $S W$ surface water

\subsubsection{Surface Water-Groundwater Exchanges}

As no groundwater uptakes were integrated into the 1900s scenario, a comparison between the 1900s and 2000s simulations clarifies the impact of groundwater uptakes on stream-aquifer exchanges (Fig. 11), showing juxtaposed locations of (1) portions of the hydrographic network for which the average stream-aquifer direction flow switches from an exfiltration mode (i.e. aquifer feeding the river) to an infiltration mode (i.e. aquifer being fed from the river) and (2) locations of the current main pumping sites, thus identifying $179 \mathrm{~km}$ of rivers where stream-aquifer exchanges are modified. At the scale of each river cell, additional simulations (not shown) distinguished the origin of the stream reversal, either climatic (shown in black in Fig. 11) or directly related to local pumping (in red). A significant perturbation of stream-aquifer relations (Table 2) by proximal pumping sites was thus 


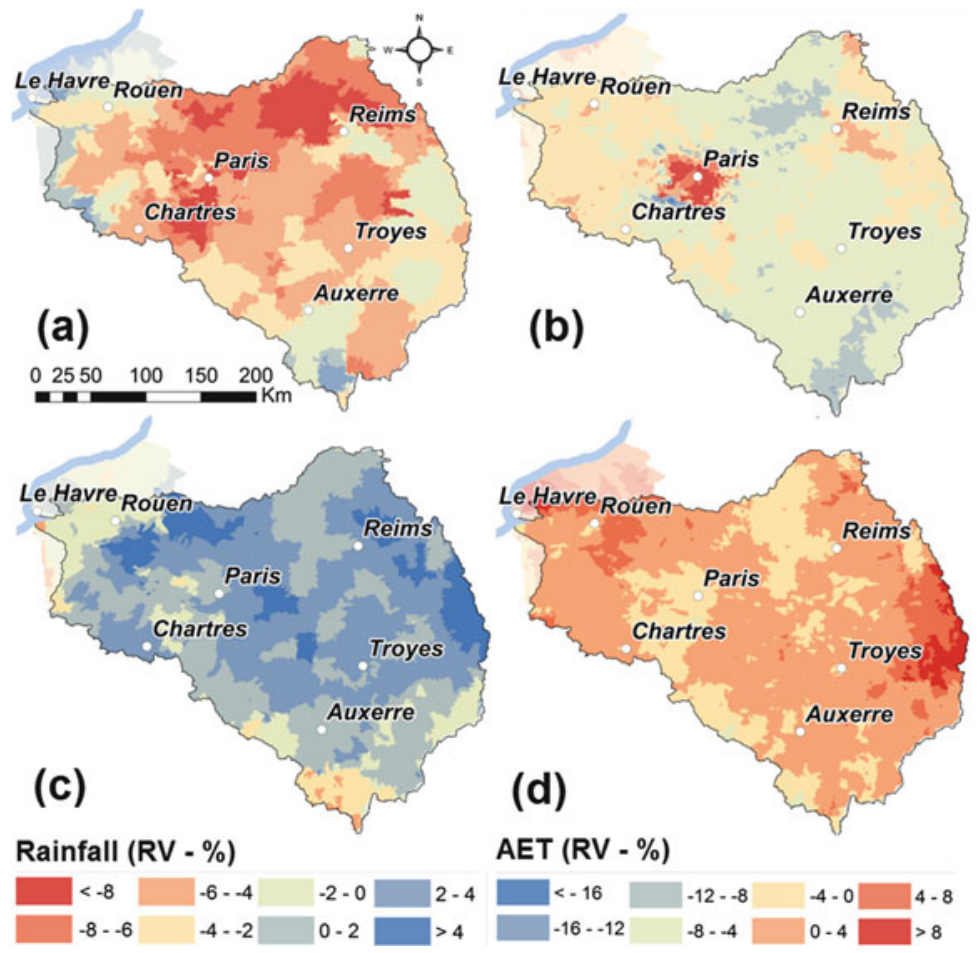

Fig. 9 Relative variations (RV) of average rainfall (a, c) and AET (b, d) for the 1900s (a, b) and 2100 s scenarios $(\mathbf{c}, \mathbf{d})$. RVs are calculated with regard to their respective reference (2000s for the 1900 s scenario and MIROC5 in the current days for the 2100s scenario)

identified since a $158-\mathrm{km}$ proportion is directly linked to groundwater uptakes. Therefore, at the scale of the Seine basin, simulated conditions in the 1900s resulted in a significant $20.9 \%$ increase of the contribution from the groundwater compartment to the surface waters. On the other hand, in the 2100 s scenario, slight variations only in fluxes from underground to surface waters are simulated when compared to the MIROC5 reference (Table 2), highlighting the relative stability of the streamaquifer exchanges.

\subsubsection{Hydrological Regimes}

A comparison approach for all three cases on simulated discharge rates was carried out to identify any significant changes in hydraulic behaviour of the main rivers. Therefore, an analysis based on the usual characteristic flow rates was conducted on eight gauging stations located either at the downstream limits of the Seine's main tributaries or along the Seine River itself (Table 3). The mean annual flow rates 


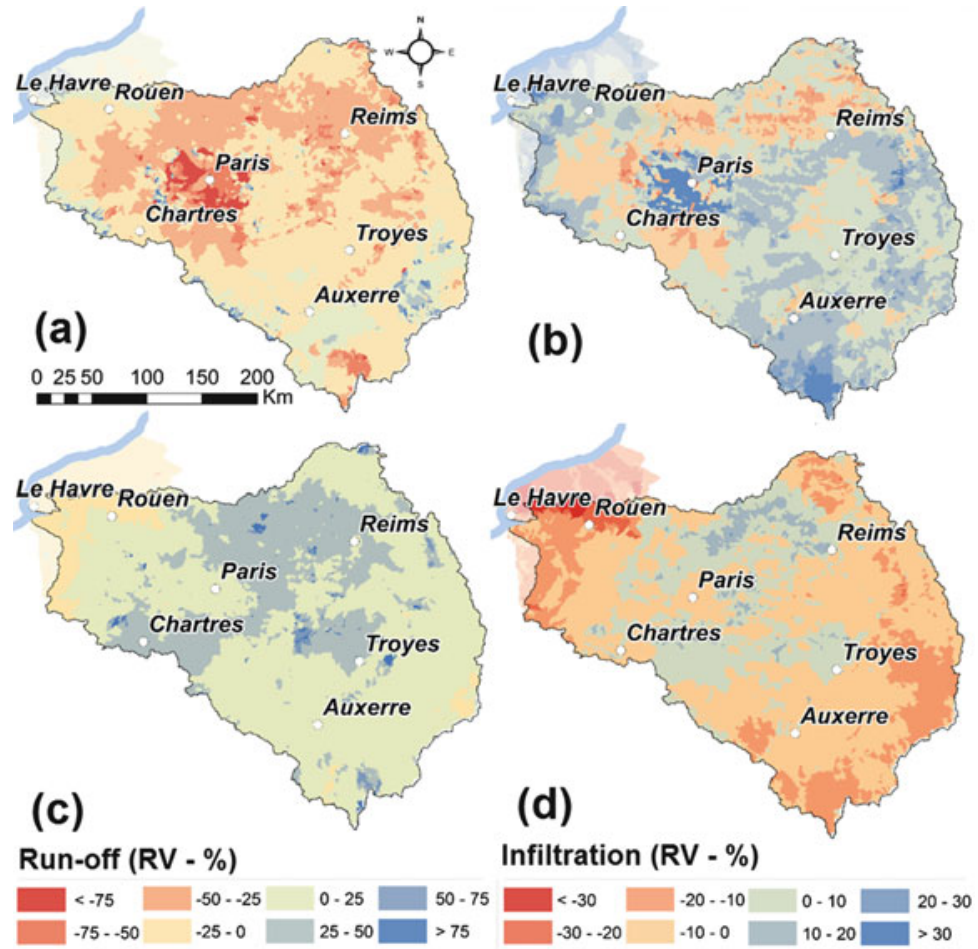

Fig. 10 Relative variations (RV) of average runoff $(\mathbf{a}, \mathbf{c})$ and infiltration rates $(\mathbf{b}, \mathbf{d})$ for the $1900 \mathrm{~s}$ (a, b) and 2100s scenarios (c, d). RVs are calculated with regard to their respective reference (2000s for the 1900s scenario and MIROC5 in the current days for the 2100s scenario)

(module) all fit around the 2000s values within a range of $\pm 10 \%$. This first-order relative stability of the average discharge has to be weighted, however, by the temporal distribution of discharges, also called regime, and the analysis of extremes, especially low-flow values. Two usual flow rates were therefore considered: (1) the annual minimum flow rate calculated over a consecutive 30-day period (VCN30) and (2) the mean monthly annual minimum discharge associated with a 5-year return period (QMNA5).

The evolution of monthly discharges is in line with previous observations on precipitation dynamics, meaning an evolution towards a winter situation characterised by an increase of mean discharge rates as opposed to a decrease in summer (Fig. 8). The hydrological regime of the Seine basin appears stable between the 1900s and the 2000s, even though (1) natural discharges decrease significantly during low flow everywhere in the basin (see QMNA5 in Table 3) and (2) the spread of the low-flow discharge also significantly decreases, meaning more recurrent low-flow periods (Fig. 8d). In September, one-third of the discharge decrease is 


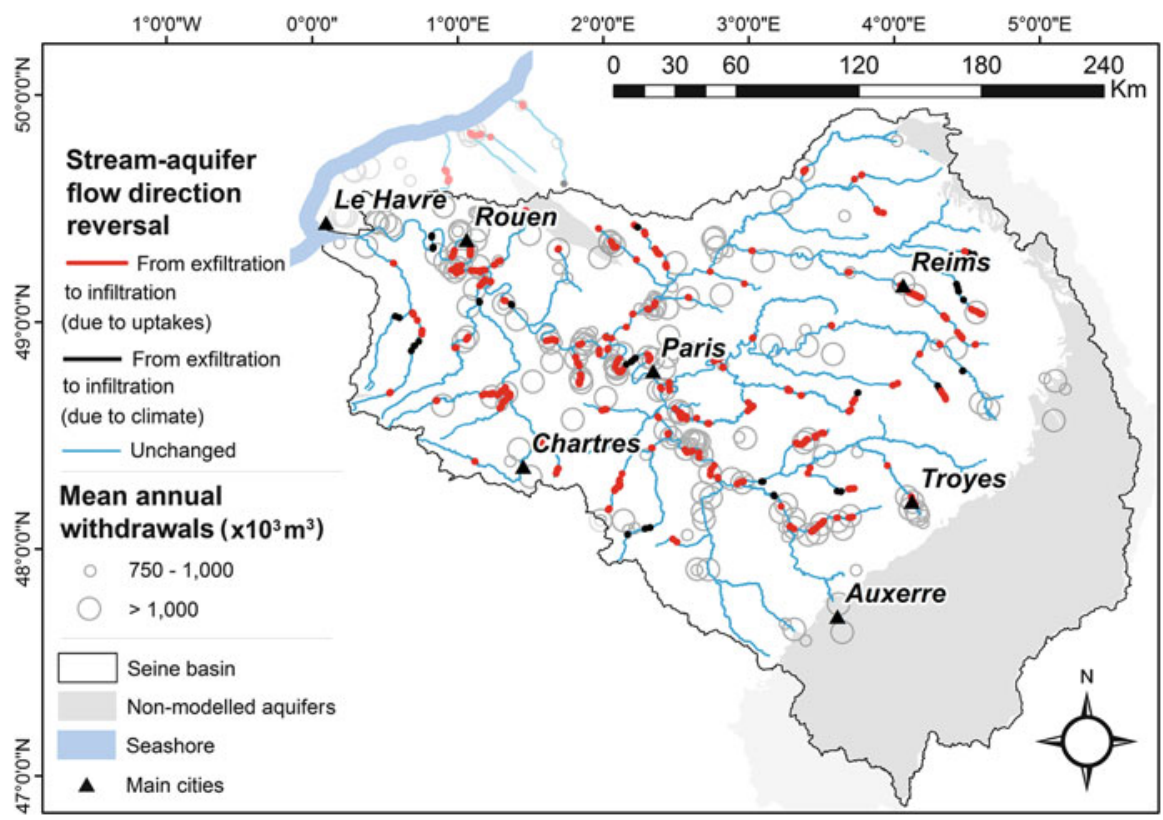

Fig. 11 Modifications of river-aquifer exchanges from the 1900s to the current scenario (2000s)

Table 3 Relative variations (RV, \%) calculated on mean monthly annual minimum discharges and mean annual discharges when compared to respective reference simulations. In the latter case, values in brackets indicate the associated relative variation of standard deviation $\sigma_{\mathrm{RV}}$

\begin{tabular}{l|l|l|l|l|l}
\hline \multirow{2}{*}{ Gauging station } & & \multicolumn{3}{|l}{ QMNA5 } & \multicolumn{2}{l}{ Mean annual discharges } \\
\cline { 3 - 6 } & Efficiency $^{\mathrm{a}}$ & $\mathrm{RV}_{1900 \mathrm{~s}}$ & $\mathrm{RV}_{2100 \mathrm{~s}}$ & $\mathrm{RV}_{1900 \mathrm{~s}}\left(\sigma_{\mathrm{RV}}\right)$ & $\mathrm{RV}_{2100 \mathrm{~s}}\left(\sigma_{\mathrm{RV}}\right)$ \\
\hline Yonne (Courlon) & 0.81 & 55.5 & -25.2 & $15.3(29.3)$ & $-2.3(19.5)$ \\
\hline Loing (Episy) & 0.57 & 32.7 & -7.2 & $16.1(2.5)$ & $3.7(15.9)$ \\
\hline Marne (Gournay) & 0.90 & 18.5 & -3.1 & $4.4(-10.3)$ & $3.3(-6.7)$ \\
\hline Oise (Pontoise) & 0.69 & 17.0 & 2.5 & $-3.5(-31.1)$ & $12.1(1.1)$ \\
\hline Seine (Bazoches) & 0.63 & 17.3 & -1.3 & $7.5(2.5)$ & $1.8(2.9)$ \\
\hline Seine (St-Fargeau) & 0.78 & 29.5 & -15.7 & $12.6(13.6)$ & $0.5(12.2)$ \\
\hline Seine (Paris) & 0.87 & 25.0 & -8.6 & $8.8(1.0)$ & $2.2(5.8)$ \\
\hline Seine (Vernon) & 0.77 & 22.9 & -5.9 & $5.6(-11.7)$ & $5.1(5.8)$ \\
\hline
\end{tabular}

${ }^{\mathrm{a}}$ Nash efficiency [95] of simulated discharges for the 2000s simulation. Location of gauging stations is displayed in Fig. 6

due to pumping, while the remaining is due to the climate itself (Fig. 8c). This trend may continue and be reinforced in the future. The overall evolution from the $2000 \mathrm{~s}$ to the 2100s may indeed lead to more abundant winter precipitation rates while being significantly reduced in the summer period (Fig. 8c, d). Although, in the case of the 2100 s simulation, no change appears to be significant enough to be notable at the 
annual scale in terms of water availability (Table 3), low-flow rate analysis clearly confirms the trend leading to lower discharges in summer (Table 3), with a progressive reduction in VCN30 spread with time, underlying a potential increase in the frequency of the occurrence of severe low-water discharges (Fig. 8d). This trend is not new and rather in line with the transformation of the hydrological regime of the Seine basin since the 1900s (Fig. 8c). These observations are in agreement with former simulations of the impact of climate change [6,9]. Climate change will have a large impact on water resources management in the future, with higher discharges in winter and lower ones from April to October. The increase of the low-flow period in the future should also lead to very critical low-flow periods in October, which emphasises the need for water management adaptation strategies.

\section{Conclusion}

Like every other river basin in the world, the Seine River basin faces global changes, either anthropogenic or climatic. The long-term environmental research programme, PIREN-Seine, allowed us to perform research on the Seine hydrosystem sustainability.

First, the analysis of long-term discharge data over 130 years at Paris displays the past trends, meaning long-term control of the discharge by climate and also the development of large water reservoirs that store $840 \mathrm{Mm}^{3}$ of water during winter and its release for sustaining low-flow discharge over $60 \mathrm{~m}^{3} \mathrm{~s}^{-1}$ at Paris. The latter has significantly transformed the hydrological regime of the Seine River by reducing the variability of monthly discharges since its implementation in the last quarter of the twentieth century.

In the last few decades, a distributed physically based coupled model of surface and subsurface flows, $\mathrm{CaWaQS}$, was also developed and progressively refined in terms of aquifer units and the river network description, as well as processes such as river-aquifer exchanges. It establishes the first published water budget of the whole Seine basin hydrosystem over a 17-year NAO oscillation period, including average exchange fluxes between aquifer layers, as well as between the river network and its underlying free aquifer units, mostly composed of an alluvial plain for Strahler orders higher than 3.

Coupled with significant progress in hydrometeorology and climate research, this model was used to assess the Seine basin hydrological trajectory from the 1900s to the 2100 s. It reveals relative stability in the average annual discharges over the entire basin over time coupled with substantial changes in the hydrological regime since the 1900 s, starting one century ago with the decrease of low-flow discharges during low flow in September and the decrease of its annual variability. This first change led to a $50 \%$ decrease of the average August discharge at the basin's outlet, one-third of it due to the gradual implementation of groundwater uptakes. The analysis of the climate 
projection under the RCP 8.5 scenario simulated with the MIROC5 model reveals a strengthening of the tendency, with another $50 \%$ reduction of the actual average August discharge, but a more worrisome increase of the low-flow period, which may extend until the end of October in the future and start 1 month earlier. This drastic mutation of the hydrological regime may be manageable considering the projected significant increase of the January and February discharges but reveals the crucial need for the elaboration of adaptation strategies for water resources management.

This work is a first analysis based on a careful selection of only one climate projection that best mimics the low frequency of the rainfall signal. It will need to be strengthened in the future by a more thorough analysis of more climate projections with the definition of a pertinent and not redundant ensemble of climate projections. The more progress made in climate projections, the more sensitive the results will be to uncertainties due to model errors and especially to processes controlling surface and subsurface exchanges, i.e. aquifer recharge processes as well as river-aquifer exchanges. The PIREN-Seine will therefore continue to dedicate a significant part of its research resources to those key scientific questions.

Acknowledgements This study is a contribution to the PIREN-Seine research programme (www. piren-seine.fr), which belongs to the Zone Atelier Seine part of the international Long-Term SocioEcological Research (LTSER) network.

\section{References}

1. Flipo N, Lestel L, Labadie P et al (2020) Trajectories of the Seine River basin. In: Flipo N, Labadie P, Lestel L (eds) The Seine River basin. Handbook of environmental chemistry. Springer, Cham. https://doi.org/10.1007/698_2019_437

2. Billen G, Garnier J, Mouchel J-M, Silvestre M (2007) The Seine system: introduction to a multidisciplinary approach of the functioning of a regional river system. Sci Total Environ 375:1-12

3. Guillocheau F, Robin C, Allemand P et al (2000) Meso-Cenozoic geodynamic evolution of the Paris Basin: 3D stratigraphic constraints. Geodin Acta 13:189-245. https://doi.org/10.1080/ 09853111.2000.11105372

4. Meehl GA, Covey C, Delworth T et al (2007) The WCRP CMIP3 multimodel dataset: a new era in climate change research. Bull Am Meteorol Soc 88:1383-1394. https://doi.org/10.1175/ BAMS-88-9-1383

5. Taylor KE, Stouffer RJ, Meehl GA (2012) An overview of CMIP5 and the experiment design. Bull Am Meteorol Soc 93:485-498. https://doi.org/10.1175/BAMS-D-11-00094.1

6. Dayon G, Boé J, Martin E, Gailhard J (2018) Impacts of climate change on the hydrological cycle over France and associated uncertainties. C R Geosci 350:141-153. https://doi.org/10. 1016/j.crte.2018.03.001

7. Déqué M, Somot S, Sanchez-Gomez E et al (2012) The spread amongst ENSEMBLES regional scenarios: regional climate models, driving general circulation models and interannual variability. Climate Dynam 38:951-964. https://doi.org/10.1007/s00382-0111053-x

8. Hattermann FF, Krysanova V, Gosling SN et al (2017) Cross-scale intercomparison of climate change impacts simulated by regional and global hydrological models in eleven large river basins. Clim Change 141:561-576. https://doi.org/10.1007/s10584-016-1829-4 
9. Habets F, Boé J, Déqué M et al (2013) Impact of climate change on the hydrogeology of two basins in northern France. Clim Change 121:771-785. https://doi.org/10.1007/s10584-0130934-x

10. Webber S, Donner SD (2017) Climate service warnings: cautions about commercializing climate science for adaptation in the developing world. Wiley Interdiscip Rev Clim Chang 8:e424. https://doi.org/10.1002/wcc.424

11. Donnelly C, Ernst K, Arheimer B (2018) A comparison of hydrological climate services at different scales by users and scientists. Clim Serv 11:24-35. https://doi.org/10.1016/j.cliser. 2018.06.002

12. Hewitt C, Mason S, Walland D (2012) The global framework for climate services. Nat Clim Chang 2:831-832. https://doi.org/10.1038/nclimate1745

13. Rockström J, Steffen W, Noone K et al (2009) A safe operating space for humanity. Nature 461:472-475. https://doi.org/10.1038/461472a

14. Kalnay E, Kanamitsu M, Kistler R et al (1996) The NCEP/NCAR 40-year reanalysis project. Bull Am Meteorol Soc 77:437-472. https://doi.org/10.1175/1520-0477(1996)077<0437: TNYRP $>2.0 . \mathrm{CO} ; 2$

15. Saha S, Moorthi S, Pan H-L et al (2010) The NCEP climate forecast system reanalysis. Bull Am Meteorol Soc 91:1015-1058. https://doi.org/10.1175/2010BAMS3001.1

16. Dee DP, Uppala SM, Simmons AJ et al (2011) The ERA-Interim reanalysis: configuration and performance of the data assimilation system. Q J Roy Meteorol Soc 137:553-597. https://doi. org/10.1002/qj. 828

17. Kobayashi S, Ota Y, Harada Y et al (2015) The JRA-55 reanalysis: general specifications and basic characteristics. J Meteorol Soc Japan Ser II 93:5-48. https://doi.org/10.2151/jmsj. 2015-001

18. Compo GP, Whitaker JS, Sardeshmukh PD et al (2011) The twentieth century reanalysis project. Q J Roy Meteorol Soc 137:1-28. https://doi.org/10.1002/qj.776

19. Poli P, Hersbach H, Dee DP et al (2016) ERA-20C: an atmospheric reanalysis of the twentieth century. J Climate 29:4083-4097. https://doi.org/10.1175/JCLI-D-15-0556.1

20. Bonnet R, Boé J, Dayon G, Martin E (2017) Twentieth-century hydrometeorological reconstructions to study the multidecadal variations of the water cycle over France. Water Resour Res 53:8366-8382. https://doi.org/10.1002/2017WR020596

21. Bonnet R (2018) Variations du cycle hydrologique continental en France des années 1850 à aujourd'hui. Université de Toulouse 3 Paul Sabatier

22. Crutzen PJ (2002) Geology of mankind. Nature 415:23. https://doi.org/10.1038/415023a

23. Crutzen PJ, Steffen W (2003) How long have we been in the Anthropocene era? An editorial comment. Clim Change 61:251-257. https://doi.org/10.1023/B:CLIM.0000004708.74871.62

24. Ellis EC, Ramankutty N (2008) Putting people in the map: anthropogenic biomes of the world. Front Ecol Environ 6:439-447. https://doi.org/10.1890/070062

25. Ellis EC, Goldewijk KK, Siebert S et al (2010) Anthropogenic transformation of the biomes, 1700 to 2000. Glob Ecol Biogeogr 19:589-606. https://doi.org/10.1111/j.1466-8238.2010. 00540.x

26. Ramankutty N, Foley JA (1999) Estimating historical changes in global land cover: croplands from 1700 to 1992. Global Biogeochem Cycles 13:997-1027. https://doi.org/10.1029/ 1999GB900046

27. Doussan C, Toma A, Paris B et al (1994) Coupled use of thermal and hydraulic head data to characterize river-groundwater exchanges. J Hydrol 153:215-229. https://doi.org/10.1016/ 0022-1694(94)90192-9

28. Doussan C, Poitevin G, Ledoux E, Detay M (1997) River bank filtration: modelling of the changes in water chemistry with emphasis on nitrogen species. J Contam Hydrol 25:129-156

29. Wei HF, Ledoux E, De Marsily G (1990) Regional modelling of groundwater flow and salt and environmental tracer transport in deep aquifers in the Paris Basin. J Hydrol 120:341-358. https://doi.org/10.1016/0022-1694(90)90158-T 
30. Gonçalvès J, Violette S, Robin C et al (2004) Combining a compaction model with a facies model to reproduce permeability fields at the regional scale. Phys Chem Earth 29:17-24. https://doi.org/10.1016/j.pce.2003.11.009

31. Gonçalvès J, Violette S, Guillocheau F et al (2004) Contribution of a three-dimensional regional scale basin model to the study of the past fluid flow evolution and the present hydrology of the Paris basin, France. Basin Res 16:569-586. https://doi.org/10.1111/j.13652117.2004.00243.x

32. Jost A, Violette S, Gonçalvès J et al (2007) Long-term hydrodynamic response induced by past climatic and geomorphologic forcing: the case of the Paris basin, France. Phys Chem Earth Parts A/B/C 32:368-378. https://doi.org/10.1016/j.pce.2006.02.053

33. Gomez E, Ledoux E, Viennot P et al (2003) Un outil de modélisation intégrée du transfert des nitrates sur un système hydrologique: application au bassin de la Seine. La Houille Blanche 3-2003:38-45

34. Saleh F, Flipo N, Habets F et al (2011) Modeling the impact of in-stream water level fluctuations on stream-aquifer interactions at the regional scale. J Hydrol 400:490-500. https://doi.org/10.1016/j.jhydrol.2011.02.001

35. Pryet A, Labarthe B, Saleh F et al (2015) Reporting of stream-aquifer flow distribution at the regional scale with a distributed process-based model. Water Resour Manag 29:139-159. https://doi.org/10.1007/s11269-014-0832-7

36. Ducharne A, Golaz C, Leblois E et al (2003) Development of a high resolution runoff routing model, calibration and application to assess runoff from the LMD GCM. J Hydrol 280:207-228. https://doi.org/10.1016/S0022-1694(03)00230-0

37. Habets F, Noilhan J, Golaz C et al (1999) The ISBA surface scheme in a macroscale hydrological model applied to the Hapex-Mobilhy area part I: model and database. J Hydrol 217:75-96

38. Rousset F, Habets F, Gomez E et al (2004) Hydrometeorological modeling of the Seine basin using the SAFRAN-ISBA-MODCOU system. J Geophys Res 109:D14105. https://doi.org/10. 1029/2003JD004403

39. Ledoux E, Gomez E, Monget JM et al (2007) Agriculture and groundwater nitrate contamination in the Seine basin. The STICS-MODCOU modelling chain. Sci Total Environ 375:33-47

40. Flipo N, Even S, Poulin M et al (2007) Modelling nitrate fluxes at the catchment scale using the integrated tool CaWaQS. Sci Total Environ 375:69-79. https://doi.org/10.1016/j.scitotenv. 2006.12.016

41. Flipo N, Jeannée N, Poulin M et al (2007) Assessment of nitrate pollution in the Grand Morin aquifers (France): combined use of geostatistics and physically-based modeling. Environ Pollut 146:241-256. https://doi.org/10.1016/j.envpol.2006.03.056

42. Ducharne A (2007) Importance of stream temperature to climate change impact on water quality. Hydrol Earth Syst Sci Discuss 4:2425-2460

43. Flipo N (2005) Modélisation intégrée des transferts d'azote dans les aquifères et les rivières: application au bassin du Grand Morin. Centre d'Informatique Géologique, Ecole Nationale Supérieure des Mines de Paris

44. Flipo N, Even S, Poulin M, Ledoux E (2005) Hydrological part of CaWaQS (catchment water quality simulator): fitting on a small sedimentary basin. Verh Internat Verein Limnol 29:768-772

45. Labarthe B (2016) Quantification des échanges nappe-rivière au sein de l'hydrosystème Seine par modélisation multi-échelle. MINES ParisTech, PSL Research University

46. Dierauer JR, Whitfield PH, Allen DM (2017) Assessing the suitability of hydrometric data for trend analysis: the FlowScreen package for R. Can Water Res J 42:269-275. https://doi.org/ 10.1080/07011784.2017.1290553

47. Boé J, Habets F (2014) Multi-decadal river flow variations in France. Hydrol Earth Syst Sci 18:691-708. https://doi.org/10.5194/hess-18-691-2014 
48. Hurrell JW (1995) Decadal trends in the North Atlantic oscillation: regional temperatures and precipitation. Science 269:676-679. https://doi.org/10.1126/science.269.5224.676

49. Hurrell JW, Deser C (2014) Northern hemisphere climate variability during winter: looking back on the work of Felix Exner. Meteorol Z 24:113-118. https://doi.org/10.1127/metz/2015/ 0578

50. Massei N, Laignel B, Deloffre J et al (2010) Long-term hydrological changes of the Seine River flow (France) and their relation to the North Atlantic Oscillation over the period 19502008. Int J Climatol 30:2146-2154. https://doi.org/10.1002/joc.2022

51. Kerr RA (2000) A North Atlantic climate pacemaker for the centuries. Science 288:1984-1985. https://doi.org/10.1126/science.288.5473.1984

52. Schlesinger ME, Ramankutty N (1994) An oscillation in the global climate system of period 65-70 years. Nature 367:723-726. https://doi.org/10.1038/367723a0

53. Hurrell JW, Kushnir Y, Visbeck M (2001) The North Atlantic oscillation. Science 291:603-605. https://doi.org/10.1126/science.1058761

54. Visbeck MH, Hurrell JW, Polvani L, Cullen HM (2001) The North Atlantic oscillation: past, present, and future. Proc Natl Acad Sci U S A 98:12876-12877. https://doi.org/10.1073/pnas. 231391598

55. Hurrell JW, Kushnir Y, Ottersen G, Visbeck M (2003) An overview of the north atlantic oscillation. Geophys Monogr Ser 134:1-35. https://doi.org/10.1029/134GM01

56. Dieppois B, Lawler DM, Slonosky V et al (2016) Multidecadal climate variability over northern France during the past 500 years and its relation to large-scale atmospheric circulation. Int J Climatol 36:4679-4696. https://doi.org/10.1002/joc.4660

57. Wang J, Yang B, Ljungqvist FC et al (2017) Internal and external forcing of multidecadal Atlantic climate variability over the past 1200 years. Nat Geosci 10:512-517. https://doi.org/ $10.1038 /$ ngeo 2962

58. Sutton RT, Dong B (2012) Atlantic Ocean influence on a shift in European climate in the 1990s. Nat Geosci 5:788-792. https://doi.org/10.1038/ngeo1595

59. Massei N, Dieppois B, Hannah DM et al (2017) Multi-time-scale hydroclimate dynamics of a regional watershed and links to large-scale atmospheric circulation: application to the Seine river catchment, France. J Hydrol 546:262-275. https://doi.org/10.1016/j.jhydrol.2017.01.008

60. Massei N, Fournier M (2012) Assessing the expression of large-scale climatic fluctuations in the hydrological variability of daily Seine river flow (France) between 1950 and 2008 using Hilbert-Huang Transform. J Hydrol 448-449:119-128. https://doi.org/10.1016/j.jhydrol. 2012.04.052

61. Galéa G, Mercier G, Adler MJ (1999) Low flow-duration-frequency models. Concept and use for a regional approach to watershed low-flow regimes in the Loire (France) and Crisu-Alb (Romania) regions. Rev des Sci l'Eau 12:93-122

62. Schuite J, Flipo N, Massei N et al Improving the spectral analysis of hydrological signals to efficiently constrain watershed properties. Water Resour Res. https://doi.org/10.1029/ 2018WR024579

63. Baratelli F, Flipo N, Rivière A, Biancamaria S (2018) Retrieving river baseflow from SWOT spaceborne mission. Remote Sens Environ 218:44-54. https://doi.org/10.1016/j.rse.2018.09. 013

64. de Marsily G, Ledoux E, Levassor A et al (1978) Modelling of large multilayered aquifer systems: theory and applications. J Hydrol 36:1-34

65. Ledoux E (1980) Modélisation intégrée des écoulements de surface et des écoulements souterrains sur un bassin hydrologique. ENSMP, UPMC

66. Ledoux E, Girard G, Villeneuve JP (1984) Proposition d'un modèle couplé pour la simulation conjointe des écoulements de surface et des écoulements souterrains sur un bassin hydrologique. La Houille Blanche (1-2):101-110

67. Ledoux E, Girard G, de Marsily G et al (1989) Unsaturated flow in hydrologic modeling theory and practice. In: Morel-Seytoux HJ (ed) NATO ASI series. Kluwer, Norwell, pp 435-454 
68. Flipo N, Monteil C, Poulin M et al (2012) Hybrid fitting of a hydrosystem model: long term insight into the Beauce aquifer functioning (France). Water Resour Res 48:W05509. https:// doi.org/10.1029/2011WR011092

69. Baratelli F, Flipo N, Moatar F (2016) Estimation of distributed stream-aquifer exchanges at the regional scale using a distributed model: sensitivity to in-stream water level fluctuations, riverbed elevation and roughness. J Hydrol 542:686-703. https://doi.org/10.1016/j.jhydrol. 2016.09.041

70. Labarthe B, Pryet A, Saleh F et al (2015) Distributed simulation of daily stream-aquifer exchanged fluxes in the Seine River basin at regional scale. In: Lollino G, Arrattano M, Rinaldi $\mathrm{M}$ et al (eds) Engineering geology for society and territory, vol 3. Springer, Berlin, pp 261-265

71. Vergnes J-P, Habets F (2018) Impact of river water levels on the simulation of stream-aquifer exchanges over the Upper Rhine alluvial aquifer (France/Germany). Hydrgeol J 26:2443-2457. https://doi.org/10.1007/s10040-018-1788-0

72. Flipo N, Mouhri A, Labarthe B et al (2014) Continental hydrosystem modelling: the concept of nested stream-aquifer interfaces. Hydrol Earth Syst Sci 18:3121-3149. https://doi.org/10. 5194/hess-18-3121-2014

73. Tóth J (1963) A theoretical analysis of groundwater flow in small drainage basins. J Geophys Res 68:4795-4812

74. Girard G, Ledoux E, Villeneuve J-P (1980) An integrated rainfall, surface and underground runoff model. La Houille Blanche 4/5:315-320

75. Deschesnes J, Villeneuve J-P, Ledoux E, Girard G (1985) Modeling the hydrologic cycle: the MC model. Part I - principles and description. Hydrol Res 16:257-272

76. Nash JE (1959) Systematic determination of unit hydrograph parameters. J Geophys Res 64:111-115. https://doi.org/10.1029/JZ064i001p00111

77. Besbes M, De Marsily G (1984) From infiltration to recharge: use of a parametric transfer function. J Hydrol 74:271-293. https://doi.org/10.1016/0022-1694(84)90019-2

78. de Marsily G (1986) Quantitative hydrogeology - groundwater hydrology for engineers. Academic Press, London

79. Rushton K (2007) Representation in regional models of saturated river-aquifer interaction for gaining/losing rivers. J Hydrol 334:262-281. https://doi.org/10.1016/j.jhydrol.2006.10.008

80. Ebel BA, Mirus BB, Heppner CS et al (2009) First-order exchange coefficient coupling for simulating surface water-groundwater interactions: parameter sensitivity and consistency with a physics-based approach. Hydrol Process 23:1949-1959. https://doi.org/10.1002/hyp.7279

81. David CH, Habets F, Maidment DR, Yang Z-L (2011) RAPID applied to the SIM-France model. Hydrol Process 25:3412-3425. https://doi.org/10.1002/hyp.8070

82. David CH, Yang Z-L, Famiglietti JS (2013) Quantification of the upstream-to-downstream influence in the Muskingum method and implications for speedup in parallel computations of river flow. Water Resour Res 49:2783-2800

83. Strahler AN (1957) Quantitative analysis of watershed geomorphology. Geophys Union Trans 38:913-920

84. de Fouquet C (2012) Environmental statistics revisited: is the mean reliable? Environ Sci Technol 46:1964-1970

85. Quintana-Seguí P, Le MP, Durand Y et al (2008) Analysis of near-surface atmospheric variables: validation of the SAFRAN analysis over France. J Appl Meteorol Climatol 47:92-107

86. Vidal J-P, Martin E, Franchistéguy L et al (2010) A 50-year high-resolution atmospheric reanalysis over France with the Safran system. Int J Climatol 30:1627-1644. https://doi.org/ 10.1002/joc. 2003

87. Wu B, Zheng Y, Tian Y et al (2014) Systematic assessment of the uncertainty in integrated surface water-groundwater modeling based on the probabilistic collocation method. Water Resour Res 50:5848-5865. https://doi.org/10.1002/2014WR015366 
88. Hunt R, Strand M, Walker J (2006) Measuring groundwater-surface water interaction and its effect on wetland stream benthic productivity, Trout Lake watershed, northern Wisconsin, USA. J Hydrol 320:370-384. https://doi.org/10.1016/j.jhydrol.2005.07.029

89. Yager RM (1998) Deftecting influential observations in nonlinear regression modelling of groundwater flow. Water Resour Res 34:1623-1633

90. Brutsaert W, Nieber JL (1977) Regionalized drought flow hydrographs from a mature glaciated plateau. Water Resour Res 13:637-643. https://doi.org/10.1029/WR013i003p00637

91. Arnold JG, Muttiah RS, Srinivasan R, Allen PM (2000) Regional estimation of base flow and groundwater recharge in the Upper Mississippi river basin. J Hydrol 227:21-40. https://doi. org/10.1016/S0022-1694(99)00139-0

92. Lyne V, Hollick M (1979) Stochastic time variable rainfall-runoff modelling. In: Proceedings of the hydrology and water resources symposium, Perth, 10-12 September,1979. Institution of Engineers National Conference Publication, pp 89-92

93. Chapman T (1991) Comment on "Evaluation of automated techniques for base flow and recession analyses" by R.J. Nathan and T.A. McMahon. Water Resour Res 27:1783-1784

94. Chapman T (1999) A comparison of algorithms for stream flow recession and baseflow separation. Hydrol Process 13:701-714

95. Nash JE, Sutcliffe JV (1970) River flow forecasting through conceptual models. $\{\mathrm{P}\}$ art $\{\mathrm{I}\}$, a discussion of principles. J Hydrol 10:282-290

96. Newcomer ME, Hubbard SS, Fleckenstein JH et al (2018) Influence of hydrological perturbations and riverbed sediment characteristics on hyporheic zone respiration of $\mathrm{CO} 2$ and N2.

Eur J Vasc Endovasc Surg 123:902-922. https://doi.org/10.1002/2017JG004090

97. Marmonier P, Archambaud G, Belaidi N et al (2012) The role of organisms in hyporheic processes: gaps in current knowledge, needs for future research and applications. Int J Limnol 48:253-266

98. Boano F, Harvey JW, Marion A et al (2014) Hyporheic flow and transport processes: mechanisms, models, and biogeochemical implications. Rev Geophys 52:603-679. https:// doi.org/10.1002/2012RG000417

99. Couturier C, Charru M, Doublet S, Pointereau P (2017) Le scénario Afterres 2050. Solagro

100. Ministère de l'Ecologie du Développement Durable et de l'Energie (2012) Explore 2070: prospective socio-économique et démographique - pressions anthropiques

101. AGRESTE (2009) La statistique agricole annuelle: Présentation générale

102. Koerner M, Cinotti B, Jussy J-H, Benoit M (2000) Evolution des surfaces boisées en France depuis le début du XIXème siècle: identification et localisation des boisements des territoires agricoles abandonnés. Rev For Fr 3:249-269. https://doi.org/10.4267/2042/5359

103. Boé J, Terray L, Habets F, Martin E (2007) Statistical and dynamical downscaling of the Seine basin climate for hydro-meteorological studies. Int J Climatol 27:1643-1655. https://doi.org/ 10.1002/joc. 1602

104. Dayon G, Boé J, Martin E (2015) Transferability in the future climate of a statistical downscaling method for precipitation in France. J Geophys Res 120:1023-1043. https://doi. org/10.1002/2014JD022236

105. Habets F, Boone A, Champeaux J et al (2008) The SAFRAN-ISBA-MODCOU hydrometeorological model applied over France. J Geophys Res 113:D06113. https://doi.org/10.1029/ 2007JDOO8548

106. Hattermann FF, Vetter T, Breuer L et al (2018) Sources of uncertainty in hydrological climate impact assessment: a cross-scale study. Environ Res Lett 13:15006. https://doi.org/10.1088/ 1748-9326/aa9938

107. Her Y, Yoo S-H, Cho J et al (2019) Uncertainty in hydrological analysis of climate change: multi-parameter vs. multi-GCM ensemble predictions. Sci Rep 9:4974. https://doi.org/10. 1038/s41598-019-41334-7

108. Ashraf Vaghefi S, Iravani M, Sauchyn D et al Regionalization and parameterization of a hydrologic model significantly affect the cascade of uncertainty in climate-impact projections. Climate Dynam. https://doi.org/10.1007/s00382-019-04664-w 
109. Maraun D, Wetterhall F, Ireson AM et al (2010) Precipitation downscaling under climate change: recent developments to bridge the gap between dynamical models and the end user. Rev Geophys 48:RG3003. https://doi.org/10.1029/2009RG000314

110. Jacob D, Petersen J, Eggert B et al (2014) EURO-CORDEX: new high-resolution climate change projections for European impact research. Reg Environ Chang 14:563-578. https://doi. org/10.1007/s10113-013-0499-2

111. Radanovics S, Vidal J-P, Sauquet E et al (2013) Optimising predictor domains for spatially coherent precipitation downscaling. Hydrol Earth Syst Sci 17:4189-4208. https://doi.org/10. 5194/hess-17-4189-2013

112. Martin ER, Thorncroft C, Booth BBB (2014) The multidecadal Atlantic SST - sahel rainfall teleconnection in CMIP5 simulations. J Climate 27:784-806. https://doi.org/10.1175/JCLI-D$13-00242.1$

Open Access This chapter is licensed under the terms of the Creative Commons Attribution 4.0 International License (http://creativecommons.org/licenses/by/4.0/), which permits use, sharing, adaptation, distribution and reproduction in any medium or format, as long as you give appropriate credit to the original author(s) and the source, provide a link to the Creative Commons licence and indicate if changes were made.

The images or other third party material in this chapter are included in the chapter's Creative Commons licence, unless indicated otherwise in a credit line to the material. If material is not included in the chapter's Creative Commons licence and your intended use is not permitted by statutory regulation or exceeds the permitted use, you will need to obtain permission directly from the copyright holder. 